\title{
The observed recent surface air temperature development across Svalbard and concurring footprints in local sea ice cover
}

\author{
Sandro Dahlke ${ }^{1,2}$ (1) | Nicholas E. Hughes ${ }^{3}$ | Penelope M. Wagner ${ }^{3}$ | \\ Sebastian Gerland $^{4}$ (이 | Tomasz Wawrzyniak ${ }^{5}$ () | Boris Ivanov $^{6,7}$ | \\ Marion Maturilli ${ }^{1}$
}

${ }^{1}$ Alfred Wegener Institute, Helmholtz Centre for Polar and Marine Research, Potsdam, Germany

${ }^{2}$ Institute of Physics and Astronomy, University of Potsdam, Potsdam, Germany

${ }^{3}$ Norwegian Ice Service, Norwegian

Meteorological Institute, Tromsø, Norway

${ }^{4}$ Norwegian Polar Institute, Fram Centre, Tromsø, Norway

${ }^{5}$ Institute of Geophysics, Polish Academy of Sciences, Warsaw, Poland

${ }^{6}$ Arctic and Antarctic Research Institute, Polar Climate Department,

St. Petersburg, Russia

${ }^{7}$ Saint-Petersburg State University,

Oceanographic Department,

St. Petersburg, Russia

\section{Correspondence}

Marion Maturilli, Alfred Wegener Institute, Helmholtz Centre for Polar and Marine Research, Telegrafenberg A45-N, 14473 Potsdam, Germany.

Email: marion.maturilli@awi.de

\begin{abstract}
The Svalbard archipelago in the Arctic North Atlantic is experiencing rapid changes in the surface climate and sea ice distribution, with impacts for the coupled climate system and the local society. This study utilizes observational data of surface air temperature (SAT) from 1980-2016 across the whole Svalbard archipelago, and sea ice extent (SIE) from operational sea ice charts to conduct a systematic assessment of climatologies, long-term changes and regional differences. The proximity to the warm water mass of the West Spitsbergen Current drives a markedly warmer climate in the western coastal regions compared to northern and eastern Svalbard. This imprints on the SIE climatology in southern and western Svalbard, where the annual maxima of $50-60 \%$ area ice coverage are substantially less than $80-90 \%$ in the northern and eastern fjords. Owing to winter-amplified warming, the local climate is shifting towards more maritime conditions, and SIE reductions of between 5 and $20 \%$ per decade in particular regions are found, such that a number of fjords in the west have been virtually ice-free in recent winters. The strongest decline comes along with SAT forcing and occurs over the most recent 1-2 decades in all regions; while in the 1980s and 1990s, enhanced northerly winds and sea ice drift can explain 30-50\% of SIE variability around northern Svalbard, where they had correspondingly lead to a SIE increase. With an ongoing warming it is suggested that both the meteorological and cryospheric conditions in eastern Svalbard will become increasingly similar to what is already observed in the western fjords, namely suppressed typical Arctic climate conditions.
\end{abstract}

\section{KEYWOR D S}

Arctic warming, climatology, observations, sea ice, surface meteorology, Svalbard 


\section{1 | INTRODUCTION}

In recent decades, the Arctic has been subject to rapid climate change that has a broad range of evolving implications for biology, the coupled climate system, economic interests and various aspects relevant for local as well as global societies. The pronounced Arctic warming (Serreze and Barry, 2011; Jeffries et al., 2013; Comiso and Hall, 2014) and Arctic sea ice retreat (Stroeve et al., 2007, 2012; Meier et al., 2014; Kim and Kim, 2017; Onarheim et al., 2018; Box et al., 2019) contribute to the Arctic Amplification of climate warming via various feedback processes (Graversen et al., 2008; Serreze et al., 2009; Screen and Simmonds, 2010; Cohen et al., 2014; Wendisch et al., 2017). While the Barents and Kara Seas exhibit the strongest winter sea ice retreat (Comiso and Hall, 2014; Kim et al., 2016; Kim and Kim, 2017), atmospheric circulation changes contribute to an enhanced winter warming in the North Atlantic region of the Arctic (Hanssen-Bauer and Førland, 1998; Isaksen et al., 2016; Dahlke and Maturilli, 2017). The third Intergovernmental Panel on Climate Change report has already pointed towards the sensitivity of the climate in the Svalbard region (IPCC, 2001). Historical climate observations on Svalbard are well documented (Hanssen-Bauer et al., 1990; Førland et al., 1997), but mostly focus on the west coast of Svalbard (Førland and Hanssen-Bauer, 2003; Nordli et al., 2014; Gjelten et al., 2016; Osuch and Wawrzyniak, 2017; Ivanov, 2019). However, a recent report of the Norwegian Environmental Agency has pointed out that "the climate of Spitsbergen interior and the surrounding islands is still rather unknown" (Hanssen-Bauer et al., 2019).

Our study addresses the recent warming period, i.e. the last four decades, with the aim to identify aspects of the recent surface air temperature (SAT) development across Svalbard including the remote fjords in the northern/northeastern sector, and to build a link to the local sea ice extent (SIE). The strong opposing west-east gradients of the climatological winter temperature, and its respective trend across the Svalbard archipelago shown in the vertical cross-section from atmospheric reanalyses in Figure 1 are the baselines of our study. Pan-Svalbard contrasts in near-surface meteorological parameters have so far been analysed only for short time periods in the order of months (Przybylak et al., 2014), missing a discussion of a potential impact on the local SIE.

The sea ice coverage in the north and east of the Svalbard archipelago was frequently perennial in the 19th and 20th centuries (Vinje, 2001; Divine and Dick, 2006), with evidence that in some years even the majority of the Greenland Sea was ice-covered, and the ice edge was located between Jan Mayen and Bjornøya (Koch, 1945; Isaksson et al., 2005). Recent sea ice conditions in the area are increasingly seasonal and have been examined in Onarheim et al. (2015) and Isaksen et al. (2016), who found that for some periods a combination of sea surface temperatures and atmospheric pressure provides a reasonable level of skill in predicting the SIE.

In the Fram Strait and surrounding Svalbard waters in particular, sea ice dynamics and extent are further affected by large-scale wind-driven transport from either the central Arctic (Trans-Polar Drift), or from the Barents Sea (Vinje et al., 1998; Kwok and Rothrock, 1999; Tislenko et al., 2016; Smedsrud et al., 2017), as well as by ocean currents.

A number of studies have examined the more accessible fjords of western Spitsbergen that already in historical times have had predominantly seasonal ice cover, since the West Spitsbergen Current (WSC) supplies oceanic heat along the west coast and up to the north-west of the archipelago contributing to the formation of a sensibleheat polynya.
F I G U RE 1 Longitude-height section of 99.9\% significant 1979-2017 winter (DJF) mean decadal warming trend (Theil-Sen method) from EraInterim in the $0-50^{\circ} \mathrm{E}$ section at $79^{\circ} \mathrm{N}$. Black contours show climatological temperature in ${ }^{\circ} \mathrm{C}$. Spitsbergen topography is schematically shown as grey contour. DJF, December-JanuaryFebruary

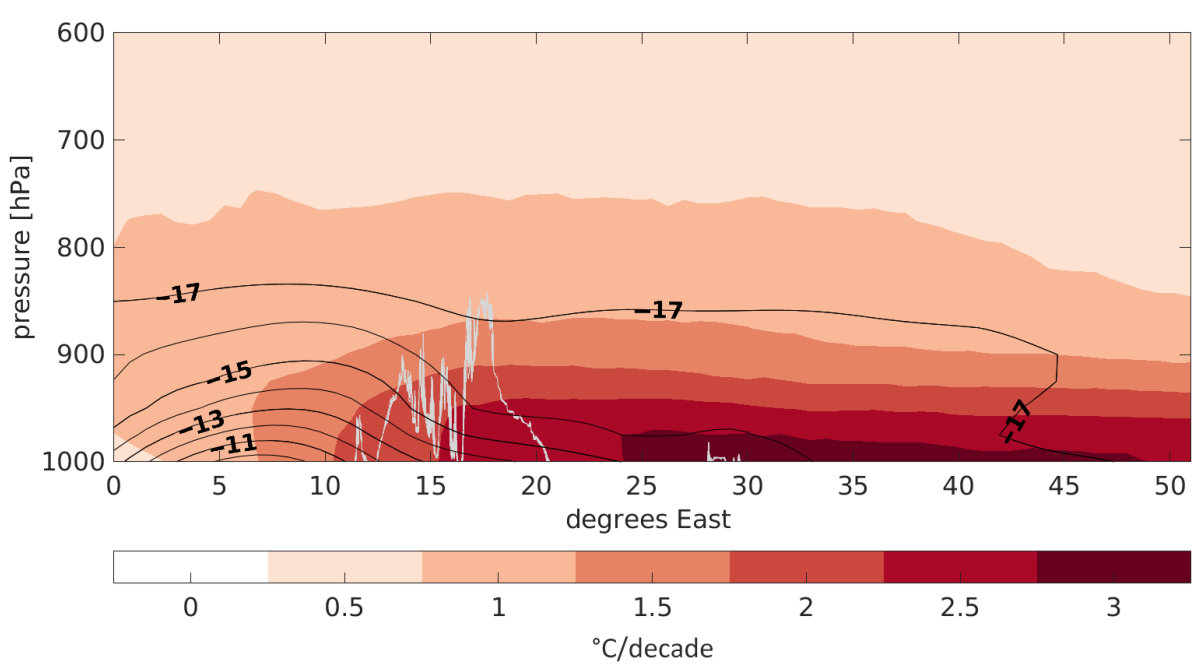


Sea ice in and around the Svalbard fjords can be characterized by seasonal fluctuations, with sea ice developing in the eastern fjords of Nordaustlandet during the freeze-up beginning in November, and then spreading to the southern Hinlopenstretet. Sea ice is typically fully developed in fjords by January, and by April, SIE becomes fully developed and highly concentrated on the eastern part of Svalbard. Detailed analyses of the sea ice conditions for single fjords or subsets of fjords are given by Muckenhuber et al. (2016) for the Isfjorden and Hornsund fjords, by Gerland and Hall (2006) for Kongsfjorden, Van Mijenfjorden and Hornsund, by Gerland and Renner (2007), Wang et al. (2015) and Pavlova et al. (2019) for Kongsfjorden, by Høyland (2009) for Van Mijenfjorden, by Hendricks et al. (2011) for Storfjorden and by Zhuravskiy et al., (2012) for Grønfjorden. A consistent delay in the start of freeze-up has been found for the Svalbard area that is expected with increased WSC temperatures. (Cottier et al., 2007).

SIE is of particular importance for the ecology of the region due to the links between the declining sea ice and the biological productivity (Ambrose et al., 2006; Leu et al., 2011; Kortsch et al., 2012).

Here, regional SIE differences across Svalbard are investigated, with an aim of quantifying the potential drivers. With our observation data based study we also intend to provide a first indication of whether the observed surface-near atmospheric winter warming is driven locally by additional heat input from the more open water fjord surfaces, or if the warmer atmosphere is the trigger for the reduced formation and preservation of the fjord sea ice. The description of the observational data and methods utilized is given in Sections 2 and 3, respectively. An overview of the pan-Svalbard surface air temperature and sea ice cover characteristics is presented in Section 4, describing climatological aspects, trends and regional differences for both components, as well as the covariance between them. The results are discussed in Section 5, and a conclusion is provided in Section 6.

\section{$2 \mid$ DATA}

\subsection{Meteorological data}

Observational data represent the baseline of this study, however, we also use temperature fields from the ERAInterim reanalysis (Dee et al., 2011) at $0.75^{\circ} \times 0.75^{\circ}$ spatial resolution. In addition, we use monthly mean SAT data from 17 meteorological stations in the Svalbard region (Figure 2) that are run by the Norwegian Meteorological Institute (MET Norway), the Polish Academy of Sciences and the Arctic and Antarctic Research Institute.

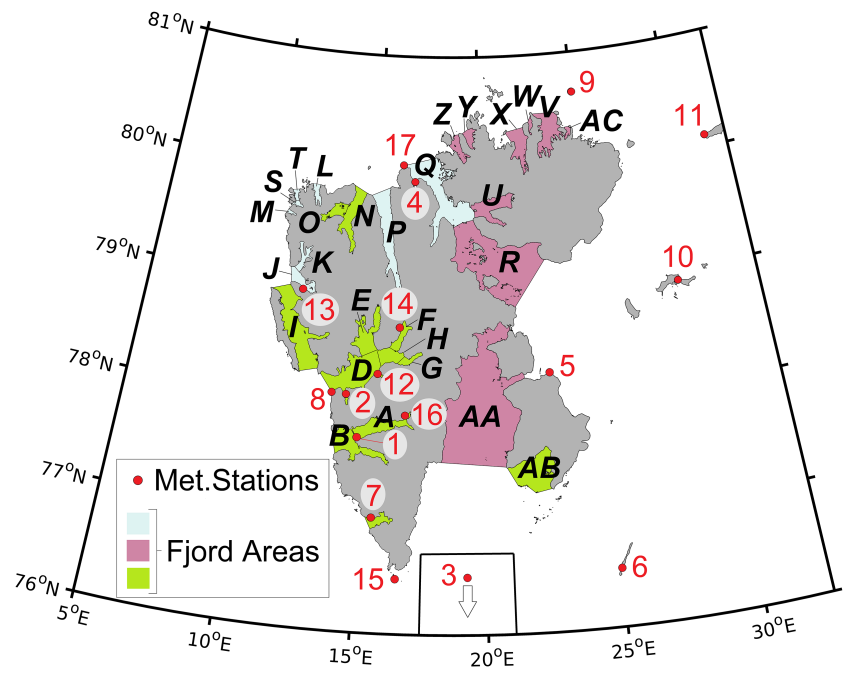

F I G U RE 2 The study area Svalbard. Red dots and numbers indicate the location of the meteorological stations, with 1 : Akseløya, 2: Barentsburg, 3: Bjørnøya, 4: Crozierpynten, 5: Edgeøya, 6: Hopen, 7: Hornsund, 8: Isfjord Radio, 9: Karl XII-øya, 10: Kongsøya, 11: Kvitøya, 12: Svalbard Lufthavn, 13: NyÅlesund, 14: Pyramiden, 15: Sørkappøya, 16: Sveagruva, 17: Verlegenhuken. Details on meteorological stations are given in Table 1. Note that the position of Bjørnøya has been shifted to fit on the map. Colouring of Fjord regions corresponds to three different patterns in the long-term development of SIE (see Section 4.2.3 for details), and letters refer to A: Van Mijenfjorden, B: Bellsund, C: Hornsund, D: Isfjorden, E: Ekmanfjorden, F: Billefjorden, G: Tempelfjorden, H: Sassenfjorden, I: Forlandsundet, J: Kongsfjorden, K: Krossfjorden, L: Raudfjorden, M: Magdalenefjorden, M: Woodfjorden, O: Liefdefjorden, P: Wijdefjorden, Q: Hinlopenstretet Nord, R: Hinlopenstretet Sør, S: Bjørnfjorden, T:

Smeerenburgfjorden, U: Wahlenbergfjorden, V: Duvefjorden, W: Zordragerfjorden, X: Rijpfjorden, Y: Brennevinsfjorden, Z: Lady Franklinfjorden, AA: Storfjorden, AB: Tjuvfjorden, AC: Finn Malmgrenfjorden

The data comprise both long-term observations at manned stations, and rather novel data from autonomous weather stations in the more remote regions, covering the last few years only. As long-term data, we refer to, and use, SAT data from the 1970-2016 period for consistency, with the aim to investigate the recent SAT development. The analysis period terminates in year 2016 due to the current lack of data accessibility for some stations (e.g., Barentsburg). For the comparison of SAT and SIE in Section 4.3, we restrict the analysis to the 1980-2016 period, as some of the long-term stations have no data available prior to the late 1970s. Details on the stations used in this study are summarized in Table 1 and are described in more detail in Hanssen-Bauer et al. (1990) and Førland et al. (1997). Regarding the analysis of longterm data, homogeneity of the time series can be influenced by changes in instrumentation, relocation of 
T A B L E 1 Svalbard meteorological stations used in this study and corresponding data availability (from 01/1970 until 12/2016) of daily 2-m air temperature

\begin{tabular}{|c|c|c|c|c|c|}
\hline Station & Lat $\left[{ }^{\circ}\right]$ & Lon $\left[^{\circ}\right]$ & elev [m] & Start date & Marked gaps \\
\hline (1) Akseløya & 77.68 & 14.78 & 20 & 08/2008- & - \\
\hline (2) Barentsburg & 78.07 & 14.23 & 75 & 01/1970- & - \\
\hline (4) Crozierpynten & 79.92 & 16.84 & 22 & 07/2010- & 07/2010-07/2012 \\
\hline (5) Edgeøya & 78.25 & 22.82 & 14 & $03 / 2006-$ & $\begin{array}{l}04 / 2006-08 / 2006 \\
02 / 2009-08 / 2010\end{array}$ \\
\hline (6) Hopen & 76.51 & 25.01 & 6 & 01/1970- & - \\
\hline (7) Hornsund & 77.00 & 15.54 & 10 & 01/1979-12/2014 & - \\
\hline (8) Isfjord Radio & 78.06 & 13.62 & 7 & 01/1970- & $\begin{array}{l}07 / 1976-08 / 1996 \\
01 / 2005-08 / 2015\end{array}$ \\
\hline (9) Karl XII-øya & 80.66 & 25.01 & 5 & 03/2016- & $\begin{array}{l}01 / 2008-06 / 2010 ; 12 / 2011 \\
02 / 2012-03 / 2013 ; 02,03 / 2014\end{array}$ \\
\hline (11) Kvitøya & 80.10 & 31.46 & 10 & 08/2011- & - \\
\hline (12) Svalbard Lufthavn & 78.25 & 15.50 & 10 & 08/1975- & - \\
\hline (13) Ny-Ålesund & 78.92 & 11.93 & 8 & 08/1974- & - \\
\hline (14) Pyramiden & 78.66 & 16.36 & 20 & $11 / 2012-$ & - \\
\hline (15) Sørkappøya & 76.48 & 16.55 & 10 & $10 / 2010-$ & - \\
\hline (16) Sveagruva & 77.90 & 16.72 & 9 & 05/1978- & 07/1979; 08,09,11/2003; 08/2004 \\
\hline (17) Verlegenhuken & 80.06 & 16.25 & 8 & $02 / 2006-$ & $\begin{array}{l}\text { Before } 10 / 2012 ; 11,12 / 2013 ; \\
01-03 / 2015,04-07 / 2016\end{array}$ \\
\hline
\end{tabular}

Note: Periods of data gaps with a length of at least 1 month are considered marked gaps. Geographical location of the stations is shown in Figure 2. We note that the Barentsburg station was relocated from 70 to $22 \mathrm{~m}$ a.s.l in 1974 and then to 75 masl in 1984, and the table gives the recent location since 1984 .

the site, or other human impact. Hence, Nordli et al. (2014) have tested and constructed homogenized longterm time series of SAT in Svalbard using data from surrounding stations. For trend analysis, we utilize these homogenized data, which are available from MET Norway for the four stations Ny-Ålesund, Bjornøya, Svalbard Lufthavn in Longyearbyen (short: Lufthavn) and Hopen. We note that all stations analysed in this study are located at altitudes between 5 and $20 \mathrm{~m}$ (75 for Barentsburg) above sea level (a.s.l., see Table 1), which therefore allows us to make direct intercomparisons of SAT.

\section{2 | Sea ice charts}

Data on sea ice around Svalbard comes from the operational monitoring of the Norwegian Ice Service (NIS), part of MET Norway, which has been producing ice charts of the conditions in the area since 1969. NIS was one of the first users of satellite data for sea ice, with Television and InfraRed Observation Satellite and National Oceanic and Atmospheric Administration images being employed from the beginning and other sensors adding with time. Prior to 1997, images were partly optical thermal infrared with spatial resolution of 1 to $4 \mathrm{~km}$, printed before the most useful cloud-free images were being traced for the weekly paper ice chart. These paper charts were the subject of a data archival and digitisation effort in the early 2000s (ACSYS, 2003). More details and analysis of this data set can be found in Vinje (2001) and Divine and Dick (2006). From 1997, ice charts have been produced digitally every weekday using electronic images and Geographical Information System software. Satellite data sources have expanded to include passive microwave imagers including SSM/I and SSMIS, AMSR-E and AMSR2 and improved optical imaging capability from AVHRR, MODIS and VIIRS. The biggest advance in ice charting capability came with access to Synthetic Aperture Radar (SAR) imaging, which provides high resolution (50-100 $\mathrm{m}$ ), all-weather imaging that covers the Svalbard archipelago on most days. After initial trials of the Canadian RADARSAT-1 in 2005, the routine has been continued with RADARSAT-2 (Scheuchl et al., 2004) since 2008, and the European Copernicus programme Sentinel-1 satellites (Torres et al., 2012) from 2015. For the SIE data used in this study, it must hence 
TA BLE 2 Sea ice concentration (SIC) classes used for the operational NIS charts

\begin{tabular}{|l|l|}
\hline Ice type & Concentration \\
\hline Fast ice & $100 \%$ fast ice \\
\hline Very close drift ice & $90-100 \%$ \\
\hline Close drift ice & $70-90 \%$ \\
\hline Open drift ice & $40-70 \%$ \\
\hline Very open drift ice & $10-40 \%$ \\
\hline Open water & $0-10 \%$ \\
\hline
\end{tabular}

be expected that quality and resolution of the ice charts was somewhat lower in the earlier years of the record, before SAR imaging became available.

Ice chart data consists of 6 sea ice concentration (SIC) classes (Table 2). Time series of the areal extent of these have been extracted for 29 fjords and straits in Svalbard (Figure 2). For the first part of the time series, prior to 1997, and during weekends, a linear interpolation of the SIE has been performed between dates where ice charts are available.

\section{3 | METHODS}

\section{1 | Trend estimation}

Throughout this study, trends and their corresponding confidence intervals are estimated using the Theil-Sen approach based on Kendall's Tau (Theil, 1950; Sen, 1968). With this method, the slope estimator is based on the median of the set of slopes between all possible data points of the series, according to:

$$
s=\underset{1 \leq i<j \leq n}{\tilde{\tilde{x}}}\left(\frac{Y\left(t_{j}\right)-Y\left(t_{i}\right)}{t_{j}-t_{i}}\right)
$$

Here, $n$ is the length of the time series, $Y\left(t_{i / j}\right)$ are observations taken at the time $t_{i / j}$, respectively and $\tilde{x}$ denotes the median operator. Other than estimates from an ordinary least squares approach, the Theil-Sen slope is a nonparametric estimator, hence the resulting trend is less affected by outliers and non-normalities in the parental distribution (Sen, 1968) and has found broad applications in climate sciences.

Autocorrelation in the time series has an impact on the significance of the estimated trend in the series (Yue et al., 2002; Steig et al., 2009a). In order to account for the effect of autocorrelation in our data, we follow a trendfree pre-whitening approach that is outlined in Yue $e t$ al.
(2002). When a seemingly significant trend is found with the Theil-Sen method, the trend component is subtracted from the data by introducing an anomaly time series.

$$
Y^{\prime}(t)=Y(t)-s \cdot t
$$

Then, the lag 1 autocorrelation coefficient $r_{1}$ is computed from the detrended data $Y^{\prime}(t)$, and removed by letting

$$
Y^{\prime \prime}(t)=Y^{\prime}(t)-r_{1} Y(t-1)
$$

In a last step, the trend component and the prewhitened anomaly series are blended by defining

$$
Y^{*}(t)=Y^{\prime \prime}(t)+s \cdot t
$$

Finally, the nonparametric Mann-Kendall test for trend detection is applied on the blended series $Y^{*}(t)$ to estimate whether the respective trend is significant after all.

\section{4 | RESULTS}

\section{1 | Surface air temperature}

\subsection{1 | Seasonal cycles of surface air temperature}

In order to identify how the local climatic conditions vary across Svalbard, SAT data from various meteorological stations from the MET Norway repository are inspected. Figure 3 illustrates differences in the SAT annual cycle between selected Svalbard stations and Ny-Ålesund as well as Kvitøya, chosen as examples for stations in the western and north-eastern Svalbard regions, respectively. Direct comparison of SAT between stations is complicated by large data gaps (see Table 1) and different operational periods among the stations, particularly with underlying long-term seasonal warming signals. Therefore, the monthly mean SAT difference is shown for those stations with more than eight complete years of data overlap with Ny-Ålesund (Figure 3a) and at least five complete years of data overlap with Kvitøya (Figure 3b). Ny-Ålesund bears characteristics of an average Svalbard station since both negative and positive SAT differences between about -3 and $+2^{\circ} \mathrm{C}$ to other stations are found, respectively. Only Bjørnøya, given its exposed geographical location several hundred kilometres south of Spitsbergen, yields much warmer monthly average SAT values throughout most of the year, but particularly in winter, when the monthly mean SAT at Bjørnøya is 
(a)

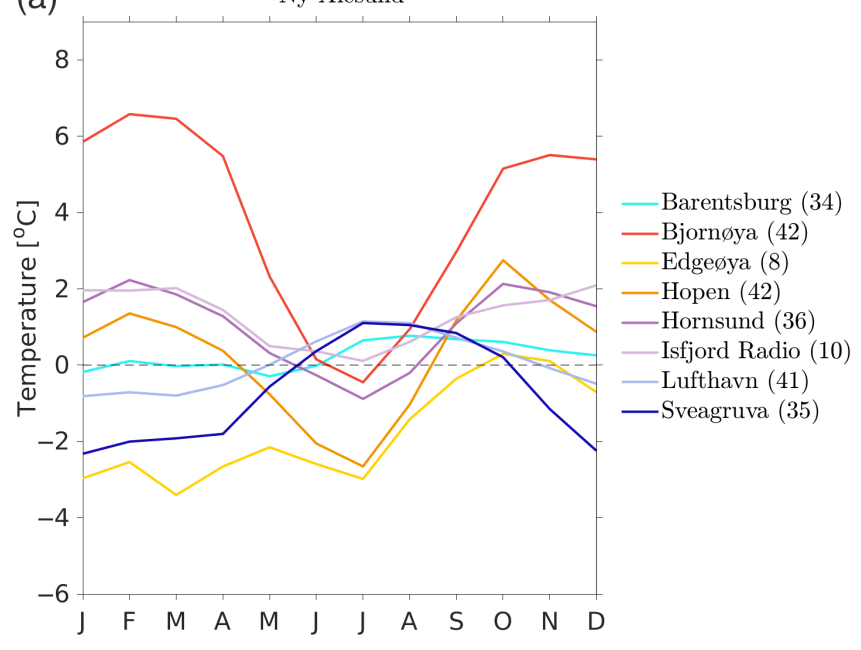

(b) Kvitøya

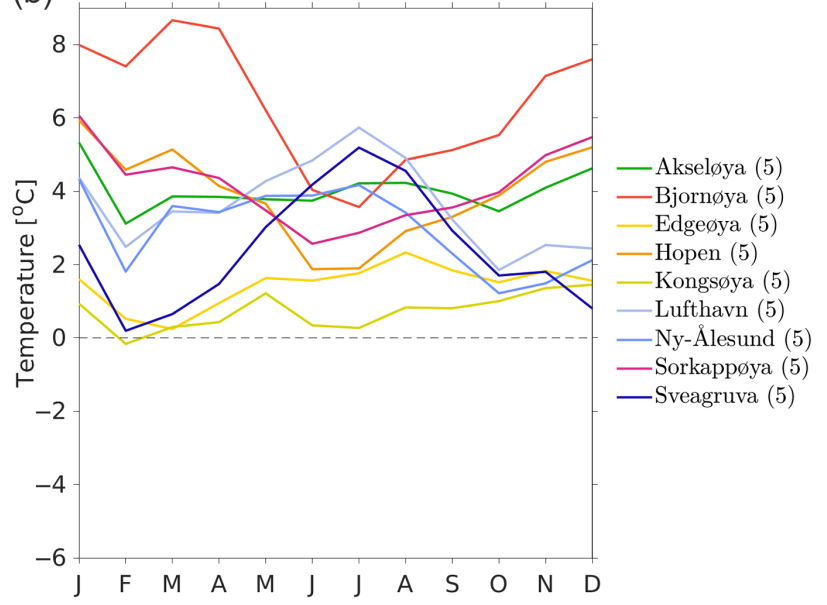

F I G URE 3 Difference of average monthly mean temperature at various Svalbard stations listed in the legend (coloured lines) to the 1970-2016 seasonal cycles of monthly SAT at stations (a) NyÅlesund and (b) Kvitøya. The number of years with overlapping data coverage with Ny-Ålesund or Kvitøya, respectively, is the basis for the average monthly SAT and given in brackets for the individual stations

more than $5^{\circ} \mathrm{C}$ higher than at $\mathrm{Ny}$-Ålesund (red curve in Figure 3a), indicative for Bjørnøya's much more subarctic maritime climate compared to the stations of the Svalbard archipelago. The contrast between stations in the south or west of Svalbard that are "Atlantic-dominated" and experience seasonal ice-cover versus the "Arcticdominated" stations in the north and east, that used to more frequently experience a year-round presence of sea ice cover is illustrated in Figure 3b, which shows the monthly mean SAT differences to the station Kvitøya as the north-easternmost station in our ensemble. Throughout the year, Kvitøya is among the coldest stations of the ensemble, as almost all other station monthly mean SATs differ by +1 to $+6^{\circ} \mathrm{C}$ (excluding Bjørnøya with more than $+8^{\circ} \mathrm{C}$ ). In contrast, the station Sveagruva reveals a pronounced seasonal cycle in the monthly mean SAT differences to both Ny-Ålesund and Kvitøya, respectively (dark blue line in Figure 3a, b). Indeed, Sveagruva is typically one of the coldest sites during winter months (November-March), while it is one of the warmest during summer (June-July-August), indicative for a rather continental climate. In fact, Sveagruva is situated in the centre of the archipelago, at the end of van Mijenfjorden and enclosed by high mountains. In early works, it has been documented that Sveagruva is among the stations with the most continental climate (Hanssen-Bauer et al., 1990; Førland et al., 1997; Przybylak et al., 2014). We can confirm these relations with our novel data, despite the rapidly changing climatic conditions and the associated reduced occurrence of winter periods with ice cover on van Mijenfjorden. The results suggest that Svalbard comprises regions of diverse climatological background situations, not only in terms of absolute values but also in terms of the annual cycle of SAT. Regarding the west-east gradient in the SAT trend (Figure 1), it is interesting to contrast the temporal evolution of the SAT fields and continentality of the Svalbard stations.

\subsection{2 | Annual temperature range}

The annual temperature range (ATR) from Svalbard stations has so far been investigated for the few available historical long-time temperature series (Gjelten et al., 2016), or in a higher spatial resolution during only one single year of observations (Przybylak et al., 2014). Here, we present climatological aspects of the ATR distribution across Svalbard, based on the station network introduced above.

Figure 4 illustrates the development of the ATR, which is defined as the SAT difference between the warmest and the coldest month of the year. As an estimate for the magnitude of the seasonal cycle of SAT, the ATR has been recognized as being a measure for continentality of the climate (Ewert, 1972; Przybylak et al., 2014; Gjelten et al., 2016), with a smaller ATR representing a more maritime climate and larger ATR a continental climate, respectively. Figure 4a shows the ATR evolution at all stations, indicating a reduction of the ATR at the long-term observational sites. For these stations, the climatological (1980-2010) ATR is shown in Figure 4b. We note that among these sites, the ATR of the stations Bjornøya, Hornsund, Hopen and $\mathrm{Ny}-\mathrm{A} l$ lesund are at least $3^{\circ} \mathrm{C}$ smaller compared to Sveagruva and Svalbard Lufthavn, indicative of the more maritime conditions in the southern and western parts of Svalbard, compared to the central part of the archipelago. To illustrate the ATR evolution in recent years, Figure $4 \mathrm{c}$ 
(a)

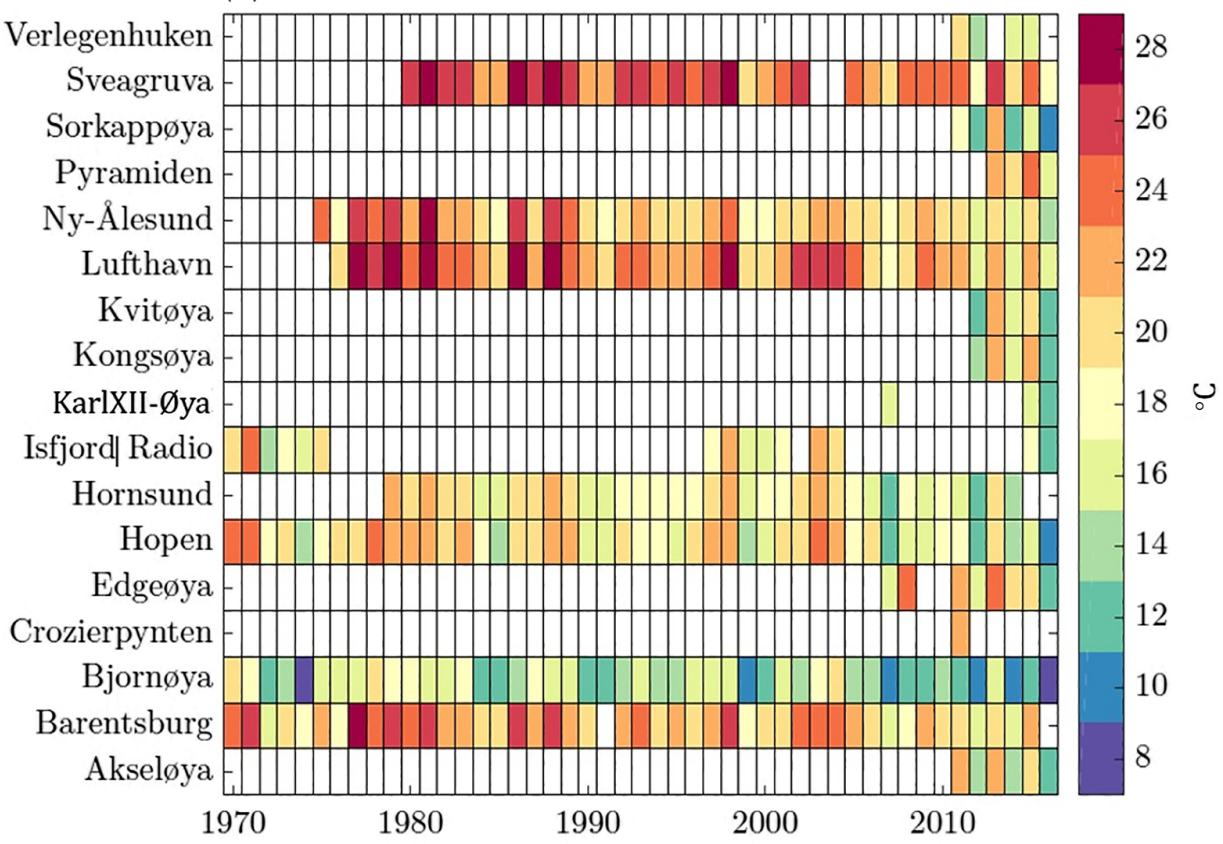

(b) $1980-2000$

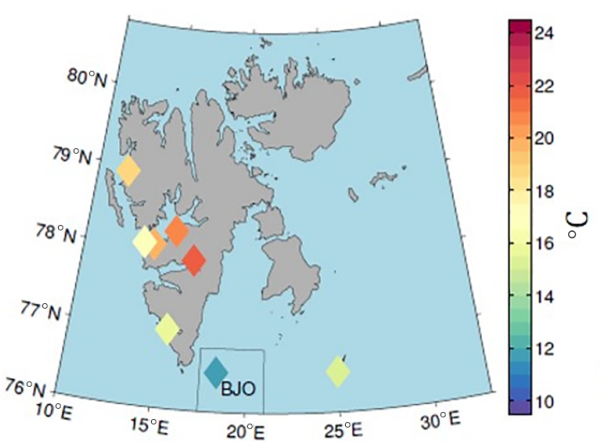

(c) 2010-2016

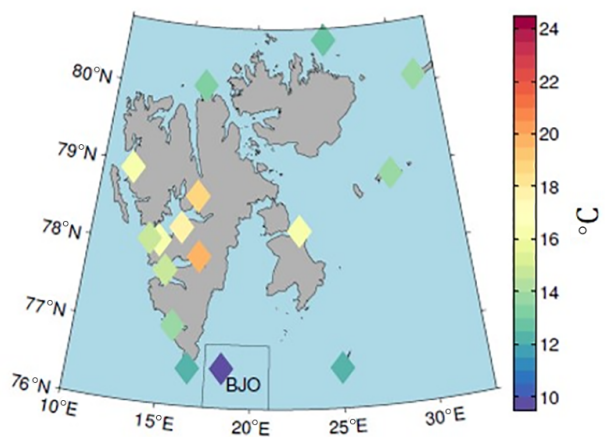

FI G URE 4 (a) Evolution of annual temperature range (ATR) for different meteorological stations on Svalbard (colour-coded, given in ${ }^{\circ} \mathrm{C}$ ). (b) Pan-Svalbard distribution of average ATR in 1980-2000. (c) As (b), but for the most recent period 2010-2016. Note that the position of Bjørnøya has been shifted to fit on the map shows the 2010-2016 ATR conditions. Interestingly, the stations in the north/northeast around Nordaustlandet also have a rather weak ATR in the latest years $\left(12-14^{\circ} \mathrm{C}\right.$ compared to $17-20^{\circ} \mathrm{C}$ in central Svalbard). This may be explained by the enhanced Arctic basin influence in these regions that drive much lower SAT compared to the other Svalbard stations, particularly during summer (cf. Figure $3 \mathrm{~b}$ with Kvitøya as an example). Compared to the climatology (Figure $4 \mathrm{~b}$ ), the ATR has decreased by about $2-3^{\circ} \mathrm{C}$ at all stations, with the consequence that the regions in central Svalbard recently yield values comparable to the climatological values in western coastal regions

\subsection{3 | Air temperature trends}

To reveal what has led to this shift towards more maritime climate conditions, we investigated the trends of monthly mean SAT at the Svalbard long-term stations: Barentsburg, Bjørnøya, Hopen, Hornsund, Svalbard
Lufthavn, Ny-Ålesund and Sveagruva. To ensure consistency, we restrict our analysis to the years 1980-2016, due to the limited data availability before 1980 at some of the long-term stations. The results are presented in Figure 5. For all stations, a positive temperature trend is found, which is strongest in the early winter season (November through February). This is indicated by the significant offset between the climatology and the decadal trend added upon the climatology. The fact that the positive temperature trend is strongest during the coldest period of the year is also the cause for the decrease in ATR, as was discussed in the previous section. Interestingly, the strongest warming trends occur prior to the month of March, which in recent years has led to March becoming the coldest month of the year at all Svalbard stations (black dashed lines in Figure 5a-g). Apart from Sveagruva, the stations exhibit rather weak $\left(<1^{\circ} \mathrm{C} /\right.$ decade $)$ but significant trends also during summer, while the trend during winter months is generally larger $\left(\approx 2-3^{\circ} \mathrm{C} /\right.$ decade $)$ but with higher uncertainties due to the higher SAT 
F I G U R E 5 (a-g): 1980-2016 temperature trends of Svalbard longterm meteorological stations. Shown is the climatology (black solid), the 2010-2016 mean (black dashed), the linear decadal trend added upon the climatology (red), and the 95\% confidence interval of the trend (ocher). Diamonds indicate if the trend is significantly different from zero. Note that temperature data are not available for all stations in the full period 1980-2016 (see Table 2).

(h) Annual mean (black) and winter mean (DJF, red) decadal trend and 95\% confidence for the stations shown in (a-g) (a)

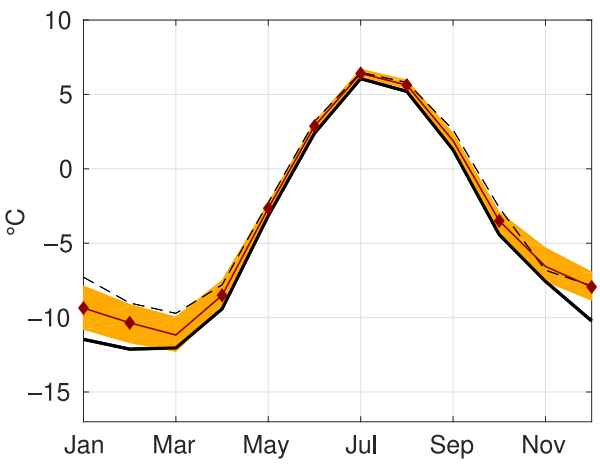

(c)

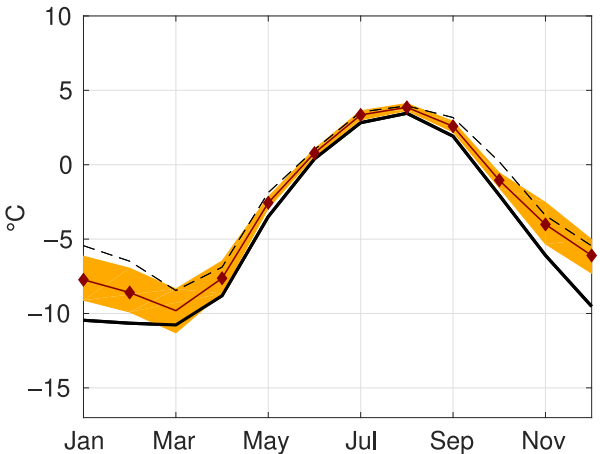

(e)

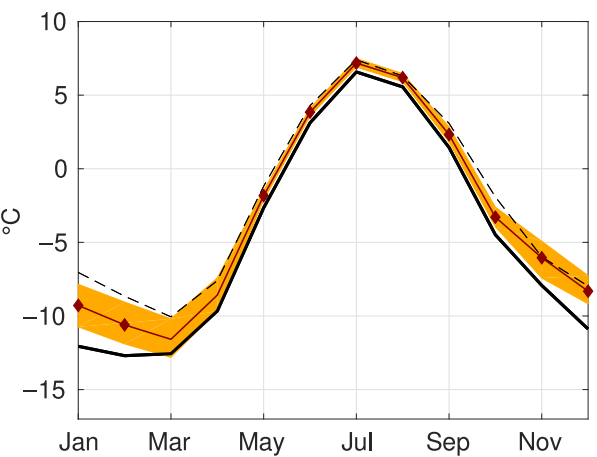

(g)

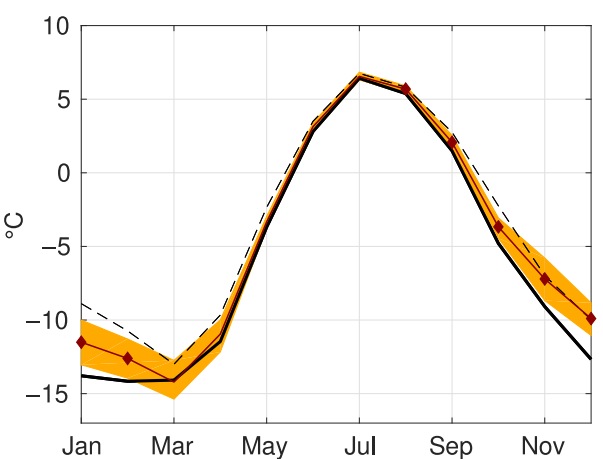

(b)

Bjornøya

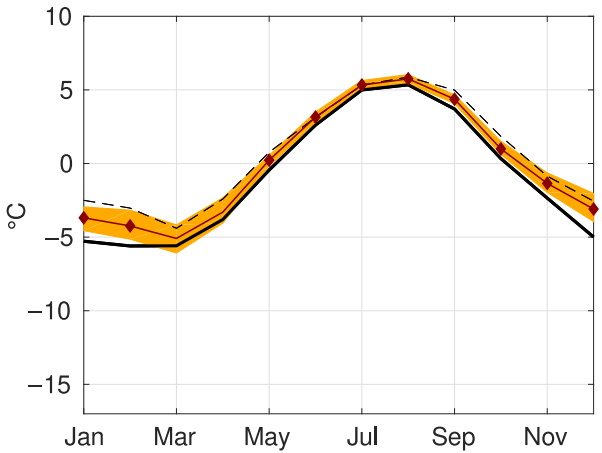

(d)

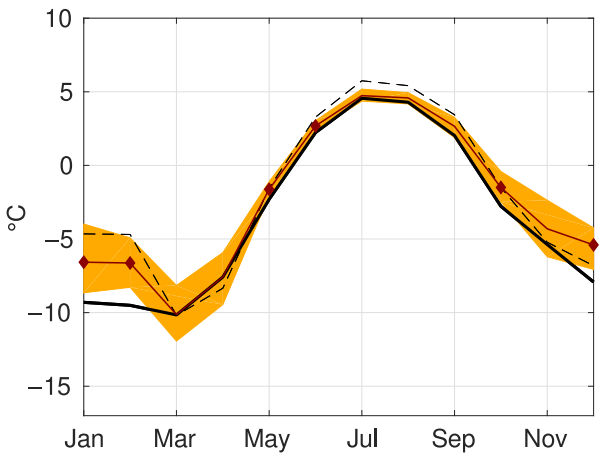

(f)

Ny-Ålesund

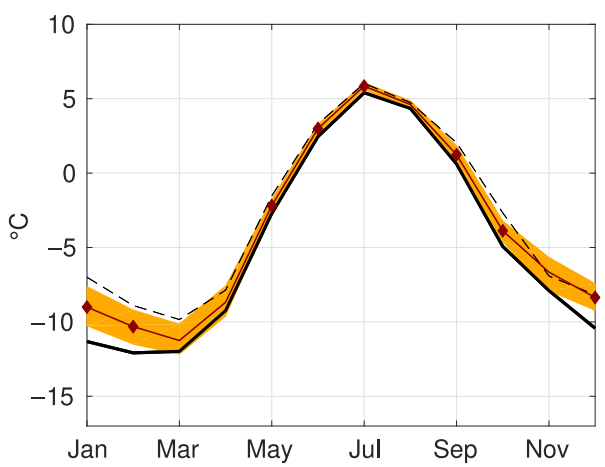

(h)

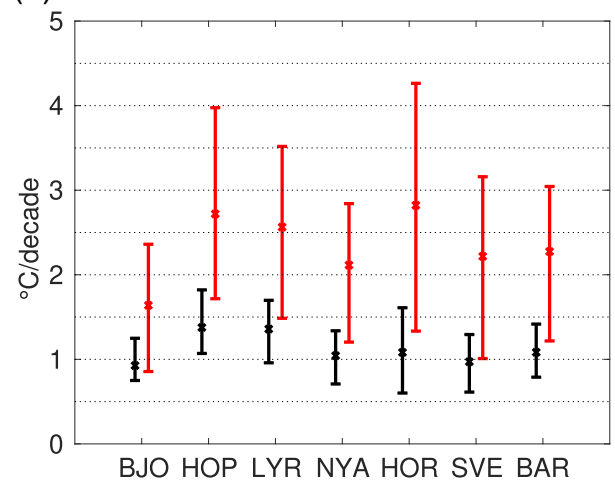

variability during winter. These differences between the SAT trends during winter compared to the annual mean is further illustrated in Figure 5h. Bjørnøya, as the southernmost analysed station several hundred $\mathrm{km}$ south of Spitsbergen, experiences the weakest trends and also the lowest trend uncertainty. Comparing the three 


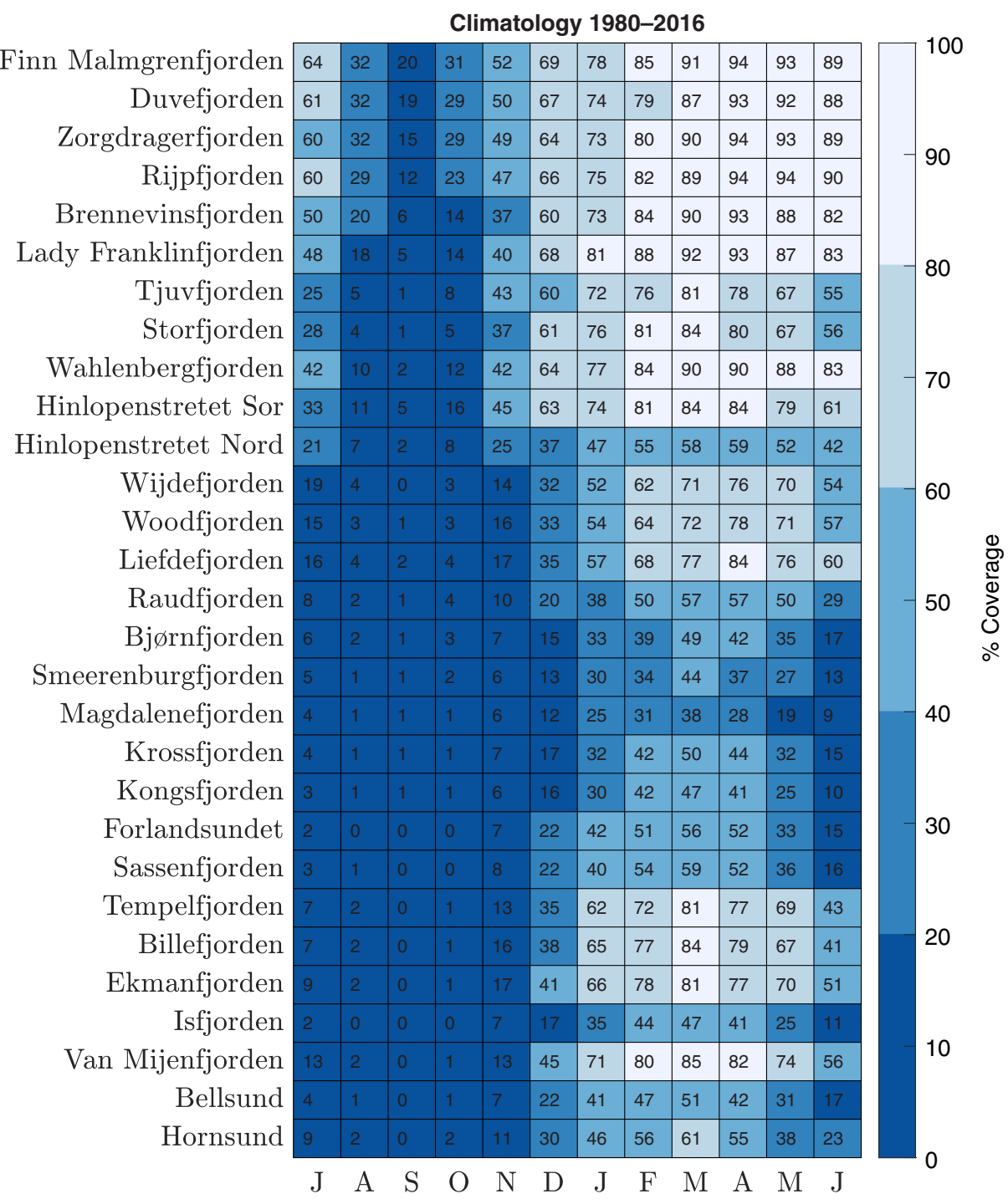

F I G U R E 6 Climatologies of 1980-2016 monthly mean SIE per region, expressed as percent area coverage. Note that the $\mathrm{x}$-axis is winter-centred stations (from west to east) Ny-Ålesund, Svalbard Lufthavn and Hopen, the wintertime SAT trend increases slightly among them $\left(2.11,2.56\right.$ and $2.72^{\circ} \mathrm{C} /$ decade, respectively, see Figure 5h), confirming the zonal gradient of the SAT trend across Svalbard seen in ERA-Interim (Figure 1). However, given the error bars, these trend estimates are not significantly different from each other. It should also be considered that this station transect is not perfectly zonally orientated as the transect along $79^{\circ} \mathrm{N}$ in Figure 1. Furthermore, the stations $\mathrm{Ny}$-Ålesund and Svalbard Lufthavn are located along the inner coastline of Kongsfjorden and Isfjorden, respectively, while station Hopen is more exposed on a narrow island in the Barents Sea where increasing ocean temperature may potentially have a stronger impact. Yet, also the SAT trends at Hornsund, Sveagruva and Barentsburg are comparable to those of the other stations.

The findings give extended insights into the progression of recent climate change in the Svalbard region, and its projections in different subregions of the archipelago.
Spatial gradients and regional differences in the annual temperature range, the seasonal cycles and SAT development stress the necessity of the continuation of routine observations, and preferably increasing the density of the existing station network to ensure higher reliability when studying climate change and the associated processes and feedbacks in the Svalbard region.

\section{2 | Sea ice coverage}

\subsection{1 | Climatology}

While floating sea ice and landfast sea ice can be present simultaneously in the fjords, satellite estimates can further contain signals of ice with glacier origin. From merged daily operational sea ice charts created by NIS, climatologies of SIE in chosen regions are presented in Figure 6. In all cases with a distinct minimum, September stands out as the month with lowest SIE, 
(a)

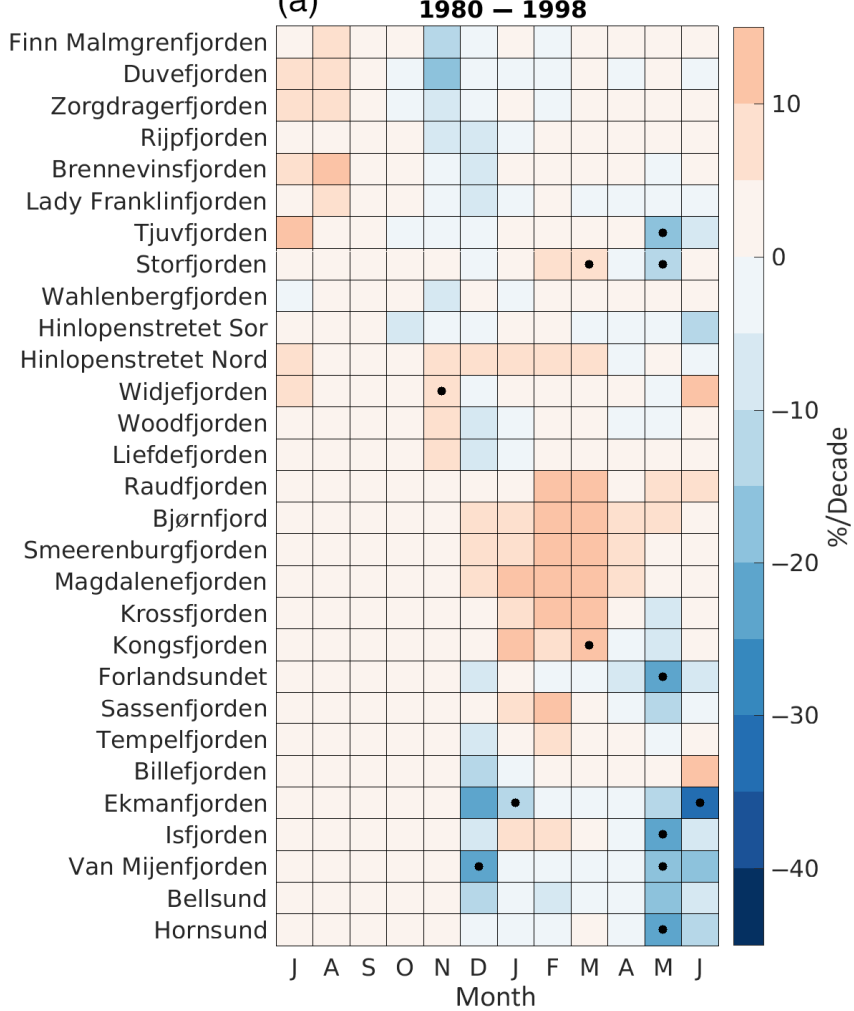

(b)

Finn Malmgrenfjorden Duvefjorden Zorgdragerfjorden Rijpfjorden

Brennevinsfjorden Lady Franklinfjorden Tjuvfjorden Storfjorden Wahlenbergfjorden Hinlopenstretet Sor Hinlopenstretet Nord Widjefjorden Woodfjorden Liefdefjorden Raudfjorden Bjørnfjord

Smeerenburgfjorden Magdalenefjorden Krossfjorden Kongsfjorden Forlandsundet Sassenfjorden Tempelfjorden Billefjorden

Ekmanfjorden Isfjorden Van Mijenfjorden Bellsund Hornsund

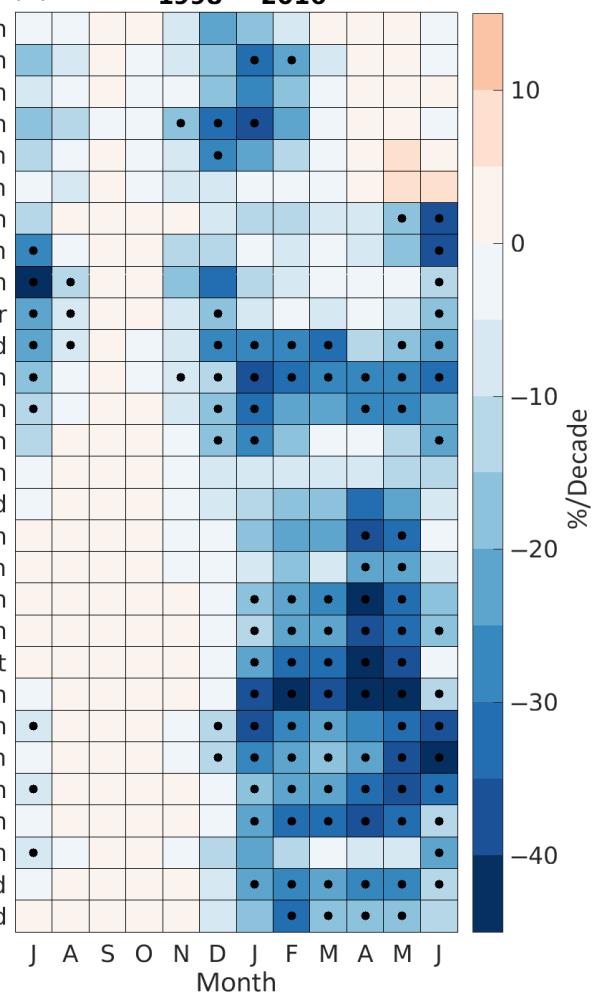

(c)

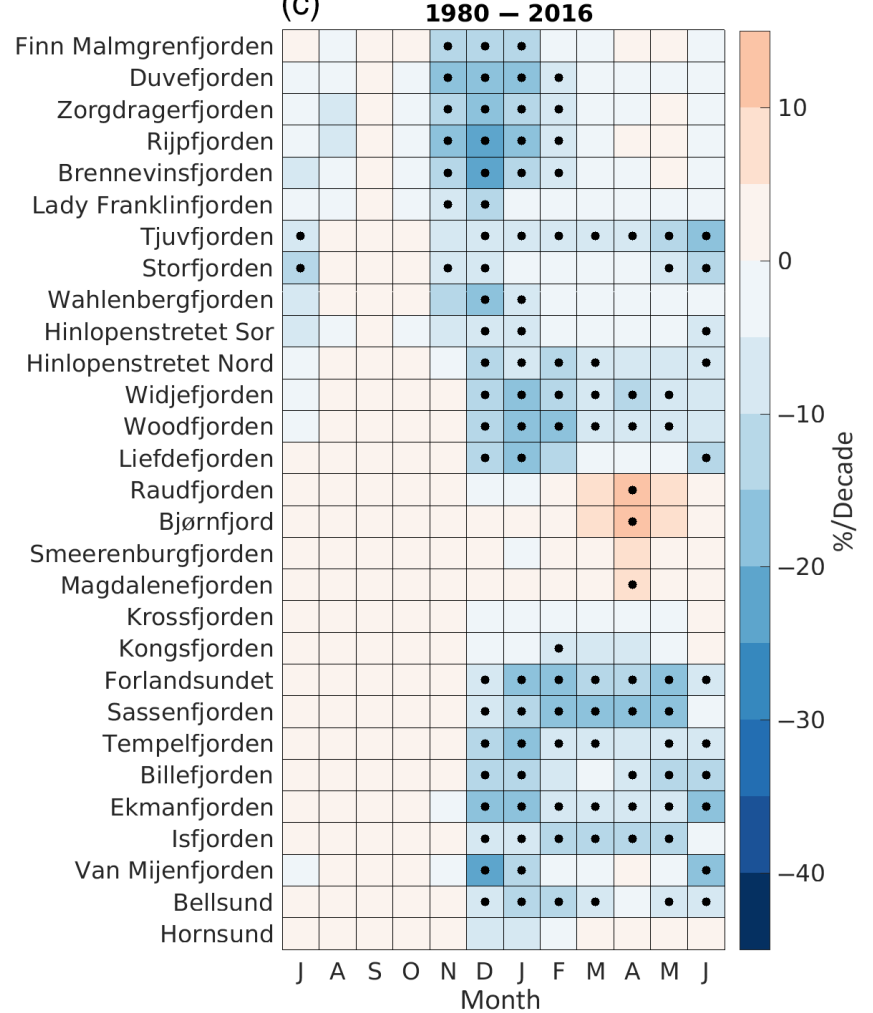

F I G U R E 7 Decadal trend of monthly mean sea ice coverage for Svalbard sub-regions for the periods (a) 1980-1998, (b) 1998-2016 and (c) 1980-2016. The trend is expressed as percent area coverage per decade. A dot indicates statistical significance (95\%) 
while the maximum SIE is observed during March/April. Several fjords/regions are virtually sea ice-free between June/July and November (panels Hornsund through Hinlopenstretet Sør in Figure 6). These fjords are clustered towards the west coast of Svalbard, where SAT is substantially higher than elsewhere on the archipelago. Additionally, intrusions of warm and saline water masses from the WSC can shape the hydrography of the western fjord's water bodies to potentially counter-act freezing (Cottier et al., 2005, 2007; Nilsen et al., 2008; Pavlov et al., 2013), a process that is less dominant in the eastern parts of Svalbard, where the East Svalbard Current carries ice and cold water southward (Hanssen-Bauer et al., 2019). As a result, the maximum SIE in winter typically does not exceed $50-60 \%$ along the west coast, while maximum SIE in the east/northeast climatologically exceeds $80 \%$ area coverage (panels Hinlopenstretet Sør through Finn Malmgrenfjorden in Figure 6). It is noteworthy that SIE in the latter regions remains on those high levels rather long into the early summer season, a time at which SIE in the former group of fjords typically has already shrunk towards the minimum. Van Mijenfjorden, Ekmanfjorden, Billefjorden and Tempelfjorden may be viewed as mixture cases in this context. While they appear as virtually sea ice-free during summer, they exhibit maximum SIE of $>80 \%$ during winter. All four of them are located in the centre of Svalbard, hence this behaviour is likely an effect of the stronger continentality with lower SAT in winter, potentially a larger freshwater availability during the freeze-up period, and more localized drainage wind regimes in these narrow fjord regions, and their hence weaker connection to larger-scale processes. Moreover, the wind field in general, but also short episodes of wind events have significant impacts on the fjord sea ice. For the case of Storfjorden, Skogseth et al. (2004) have demonstrated that large areas of the fjord are either freezing or building a polynya, dependent on $\mathrm{N}$ or $\mathrm{S}$ wind direction. In the more sheltered, narrow fjords on Svalbard, in contrast, winds are often characterized by localized, often katabatic regimes. As a complex interplay of different mechanisms like channelling, valley drainage and gravity waves impacts the fjord valley's wind fields (Esau and Repina, 2012), studying how the local surface wind field drives variability both in SIE and SAT remains challenging.

\subsection{2 $\quad$ Trends}

Long-term variability of sea ice cover and thickness in the broader region around Svalbard and various individual Svalbard fjords in the more accessible west have been frequently explored (e.g., Gerland et al., 2008; Zhuravskiy et al., 2012; Onarheim et al., 2014; Isaksen et al., 2016; Muckenhuber et al., 2016; King et al., 2017; Onarheim et al., 2018; Rösel et al., 2018; Pavlova et al., 2019). However, according to our knowledge there was no pan-Svalbard synthesis that would include the more remote fjords in the north and east. In this section, we present trend estimates for 29 Svalbard subregions (Figure 2). Monthly means were calculated for the years since 1980 to obtain long-term trends in SIE. The results are shown in Figure 7 for three different periods. To particularly highlight the SIE development in recent years, the sub-region trends for the earlier period 1980-1998 (P1 in the following) are contrasted with the more recent years 1998-2016 (P2 in the following). The trends for the entire period 1980-2016 are also provided, and it appears that SIE has declined significantly by about $5-20 \%$ per decade in most of the Svalbard subregions from December through early summer. An exception is the northwestern-most part of Spitsbergen, from Kongsfjorden in the south to Raudfjorden in the north, where no conclusive pattern of significant trends was found. These four regions of weak or no trends are clustered in the north-western part of the archipelago (see Figure 2b), where the warm and saline Atlantic water masses of the West Spitsbergen Current may have a potential impact on local sea ice conditions (Cottier et al., 2007). We note however that several fjords are almost ice-free from summer to November (Figure 6), hence spurious trends in these months in relevant regions should not be physically interpreted. Moreover, signals of decreasing SIE in the eastern and northeastern regions, that is, the uppermost panels in Figure $7 \mathrm{a}-\mathrm{c}$, begin in November and end in mid-winter. It is expected that signals of declining SIE will be pronounced most strongly in the typical freeze up season, and the above mentioned fjords are located in the north-east of Svalbard, where much lower temperatures compared to the west drive an earlier onset of the freeze-up season. In late winter, the regions around Nordaustlandet are still cold enough to yield freezing conditions, and during 1980-2016, no significant SIE decline is evident. When comparing Figure $7 \mathrm{a}, \mathrm{b}$ it becomes clear that the majority, if not all of the observed SIE reduction, is due to the latest years during period P2. In the period P1, no consistent pattern of trends is emerging from the different regions. Between Kongsforden and Raudfjorden, there is even a tendency of increasing SIE during the winter months in P1 that occurs at those places with weak or no trend when taking into account the entire period 1980-2016 (Figure 7c). However, these positive trends during P1 are largely insignificant. During P2, in contrast, 
(a)

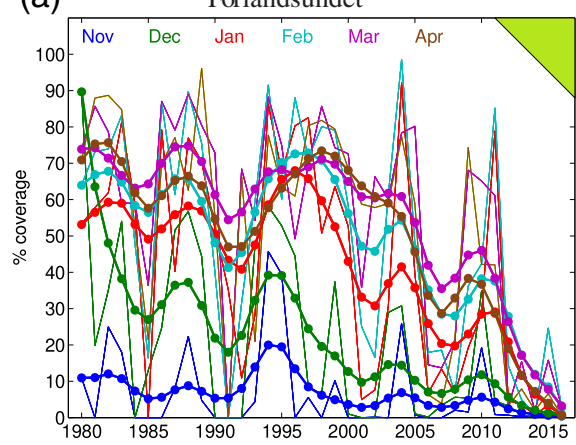

(d)

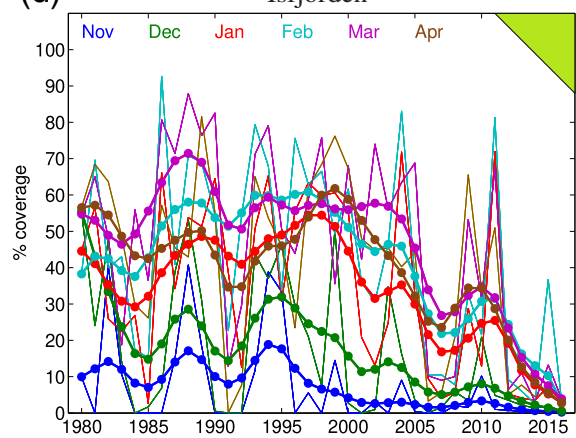

(g)

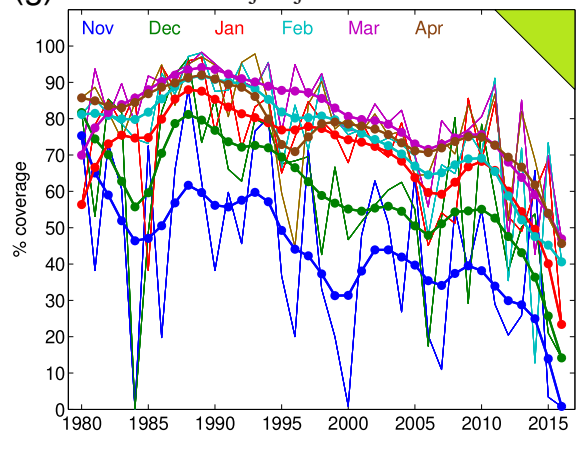

(b)

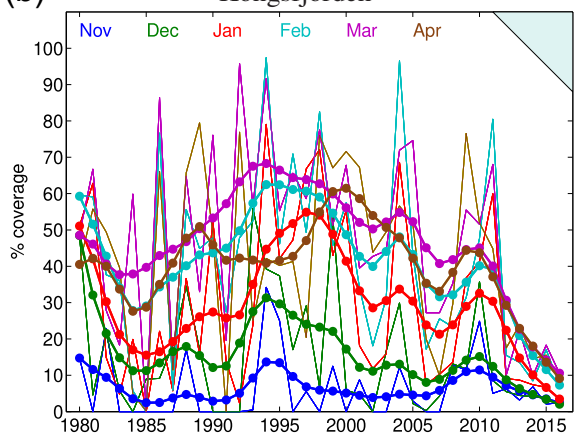

(e)

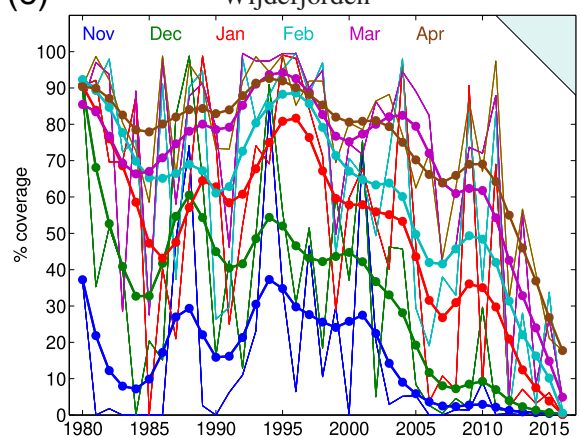

(h)

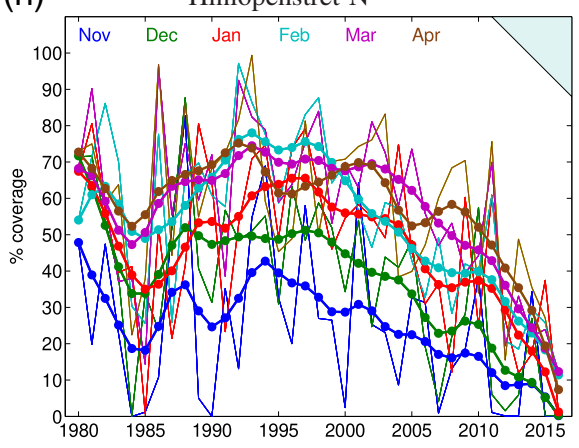

Pattern 2 (c)

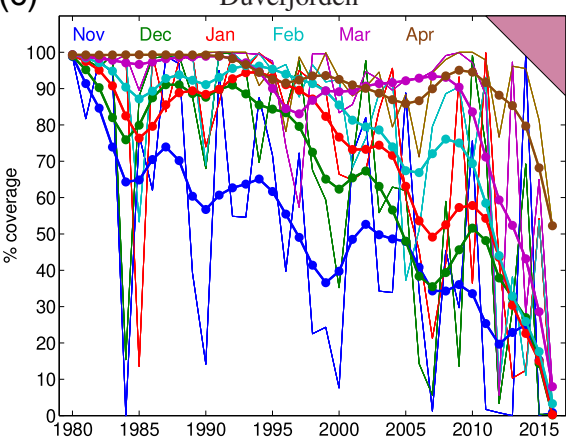

(f)

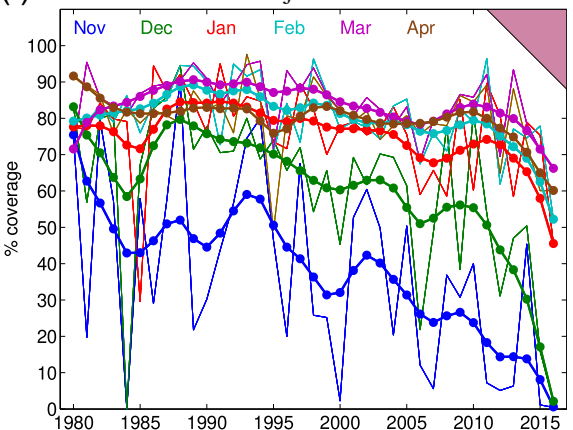

(i)

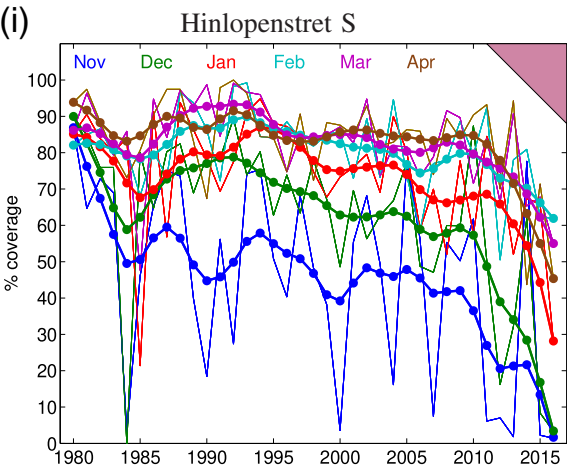

Pattern 3

F I G U R E 8 Sea Ice Extent for nine selected Svalbard fjords/regions for the months November (blue), December (green), January (red), February (light blue), March (violet) and April (brown), respectively. Thin lines are monthly mean estimates, while heavy dotted lines are monthly mean estimates with an 8-year low pass filter applied. Colour shading in the upper right corner reflects the affiliation to one of the three identified patterns of long-term variability (see text)

significant SIE reduction exceeding $20 \%$ and locally even $30 \%$ per decade is observed during the extended winter season in most fjord regions of Svalbard, pointing to a rather parallel behaviour of the sea ice cover across the archipelago. However, several of the sub-regions do not exhibit such widespread, significant SIE reduction during 1998-2016. Van Mijenfjorden, Raudfjorden, Lady Franklinfjorden, Zordrangerfjorden and Finn Malmgrenfjorden may be listed as examples. The differences in the long-term SIE development of the Svalbard sub-regions are analysed in the following section.

\subsection{3 | Regional differences across Svalbard}

For a more thorough classification of regional SIE peculiarities, time series from the 29 sub-regions were analysed. According to patterns in the long term SIE development in the late cold season (March-April), the sub-regions were grouped into the following three distinguished categories that are highlighted by color-coding in Figure 2:

1. No or weak SIE reduction until 2000, with acceleration in recent years (pattern 1-western coast, green) 
2. Increasing SIE in the $1980 / 90$ 's, followed by a strong decrease (pattern 2-north/northwest, blue)

3. Virtually full sea ice cover until 2010, followed by strong decrease in recent years (pattern 3-north/ north-east, pink)

Although this classification is done by individual inspection of each time series, and in some cases is challenging to assign a defined pattern to a specific region, the method yields valuable insights into how SIE evolution differs across Svalbard. In Figure 8, three representative examples for each of the three categories are presented. In all locations across Svalbard, the strong seasonality of SIE is a dominant feature, with low SIE in November, increasing during the following months until the maximum is reached by late winter. As the SIE is characterized by strong interannual variability, low pass filtered series of March and April are utilized to describe further features. For pattern 1 (green areas in Figure 2) before the year 2000, interannual variability dominates and no conclusive statements can be drawn on the presence of any other tendency. After the year 2000, a strong downward trend dominates the series, with SIE approaching $0 \%$ in some regions at the end of the time series. The same SIE decline is evident in pattern 2 (blue) along the Northern coast of Svalbard, but in contrast to pattern 1, SIE has had an increasing tendency during the 1980s and 1990s. The lower data quality and coverage of the sea ice maps during that time, which has increased a lot with the availability of SAR images from 2005 on (Muckenhuber et al., 2016) should be considered. However, the 1985-1995 SIE increase appears in the monthly mean estimates in several different fjords, which leads us to conclude that the feature is relevant. Moreover, pattern 2 is orderly confined to the northern and northwestern sector of Svalbard (Figure 2), where wind-driven sea ice advection from the north may have an impact. In fact, a number of studies concerning the variability of sea ice export through Fram Strait identify an increase of the southward sea ice flux from a minimum in 1985 towards a maximum in 1995 (Vinje et al., 1998; Kwok and Rothrock, 1999; Hilmer and Jung, 2000; Smedsrud et al., 2017). This is in line with our observations on SIE variability in pattern 2 of Svalbard fjords and promotes the hypothesis that wind-driven ice drift may explain these regional aspects. More details on this potential link are given in the Section 5.

Pattern 3 includes the fjords and straits in the northeast and east of the Svalbard archipelago. As mentioned above, these regions are generally characterized by virtually full, or close to full area coverage in late winter SIE before 2010, with only small interannual deviations. After 2010, however, the marked sea ice decline commences also in these vicinities during late winter. Note that nevertheless, in recent years the fjords and straits of pattern 3 have seen substantial fractional sea ice extents of more than 50\% in March and April (Figure 8c, f, i). This is in sharp contrast to most fjords of patterns 1 and 2, where even in the unfiltered monthly mean data, after the last maximum of 2011, SIE has not exceeded $20 \%$ area coverage. This is a consequence of the zonal SAT gradient across Svalbard, and hence the still much higher fraction of days with freezing conditions in the east compared to the west. For the example of Kongsfjorden, our findings are consistent with fast-ice coverage estimates in Pavlova et al. (2019), including the sharp decrease in SIE after 2006 and 2012. The same holds for the comparison with Isfjorden sea ice concentration investigated by Muckenhuber et al. (2016). Zhuravskiy et al. (2012) further report a later onset of freezing, and shrinking thickness of fast-ice in Gronfjorden from 1974 to 2008.

Our results promote the view of regionally differing cryospheric conditions in the fjords and straits of Svalbard, with a gradient from the southwest to the northeast of the archipelago. This also implies that sea ice observations and associated processes, that emanate from the extensively sampled fjords on the west coast are not necessarily applicable to the whole Svalbard region, especially considering the northern and the eastern sector, where different processes are at play. On the other hand, with an ongoing SIE decline in the pattern 3 sector, it appears likely that this region will become more similar to the western parts of Svalbard, as the near surface warming and SIE decline is expected to be amplified in the future (Stroeve et al., 2012; Lind et al., 2018).

\section{3 | Covariability between SAT and SIE}

It is important to note that SIE distribution in the fjords is not only a function of the temperature but is altered by various additional processes in the ocean-atmosphere system. It is beyond the scope of this study to investigate these processes in detail, but rather to stress and document the covariability between SIE and SAT in the region of rapidly changing climatic conditions. However, one would expect an inverse relationship between SAT and SIE, as high temperatures promote low ice conditions and vice versa. Yet, the presence of sea ice has an effect on the formation and maintenance of surface based temperature inversions. During summer, the smaller albedo due to reduced SIE affects the SAT by increased absorption of solar radiation. Moreover, SIE reduction in the fjords, by leaving larger areas of open water, has the potential to drive SAT warming via the release of additional heat and moisture to the atmosphere, which in 


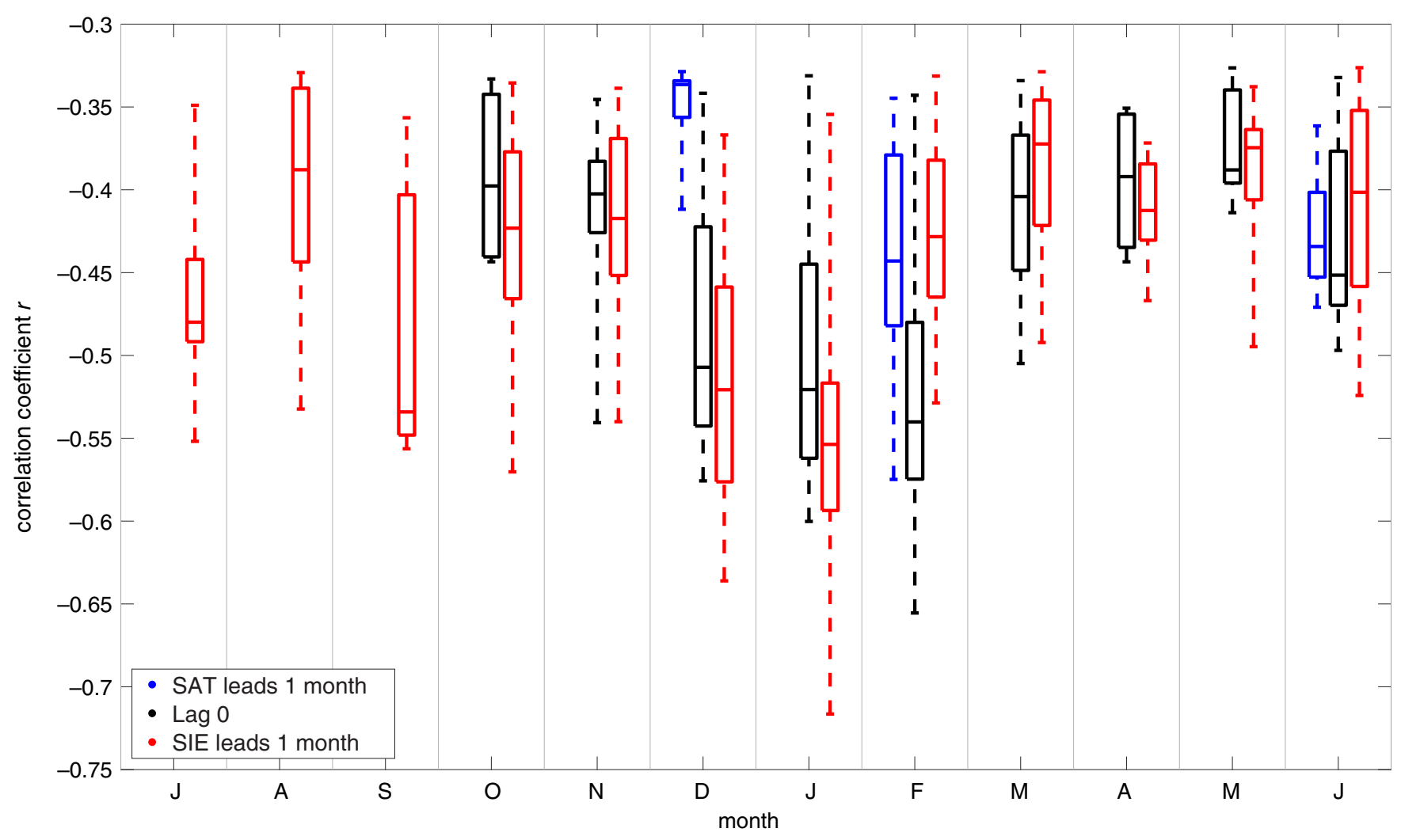

F I G U R E 9 Each black whisker represents the set of significant (95\%) correlation coefficients between monthly mean SAT in NyÅlesund and SIE in all 29 sea ice regions during the displayed month. Blue (red) whiskers correspond to correlations when SIE is lagging (leading) SAT in the displayed month by 1 month, respectively. Each box encloses the 25-50th percentile range of correlation coefficients, the horizontal line denotes the median and the whiskers cover the whole range

turn enhances downward long wave radiation. However, the importance of this "sea ice-insulation feedback" has been stressed for the large-scale Arctic mostly (Burt et al., 2016; Kim et al., 2019). In order to investigate and quantify these relations between sea ice conditions and SAT across Svalbard, we compute lead-lag Pearsoncorrelations on the monthly mean SAT and SIE estimates. Statistical significance of correlations is tested by a two-sided t-test against the null hypothesis that the true correlation is zero, and time series have been linearly detrended before calculating correlations. Figure 9 sums up the findings for the exemplary case of Ny-Ålesund SAT and SIE across Svalbard. We focus the interpretations on winter and spring due to the above discussed seasonality of the Svalbard SIE. It can be seen that significant instantaneous correlations (black boxes) are found for each month between October and July, but strongest during December, January and February, with the median correlation coefficients among the different ice regions exceeding -0.5 .

Lead-lag correlations can be useful in order to infer causality of these relations. For the case of SAT affecting the SIE in the following month (red boxes), significant correlations are consistently established throughout the year, with maximum values in December and January. The lagged coefficients are generally comparable to those of the instantaneous ones, but it is interesting that through October-January, they are slightly higher than those for the instantaneous correlations. Sets of significant lagged correlations are even found for the summer months, when no significant instantaneous correlations are present. This reflects how large-scale temperature patterns, which affect Ny-Ålesund, can project on the SIE in the north and northeast of Svalbard, where there are non-negligible fractions of SIE available during summer. This promotes the view that sea ice, given its rather long memory, is prone to the effect of SAT forcing from the previous weeks. When consulting lagged correlations in the other direction, namely with SAT anomalies following SIE anomalies after 1 month (blue boxes in Figure 9), median correlation coefficients are generally weaker than the ones for instantaneous correlations, and during winter and spring, they only appear in 2 months. This leads us to conclude that SAT anomalies exert a direct effect on SIE in the fjords and straits across Svalbard. The above results are based on SAT from the station Ny-Ålesund, 


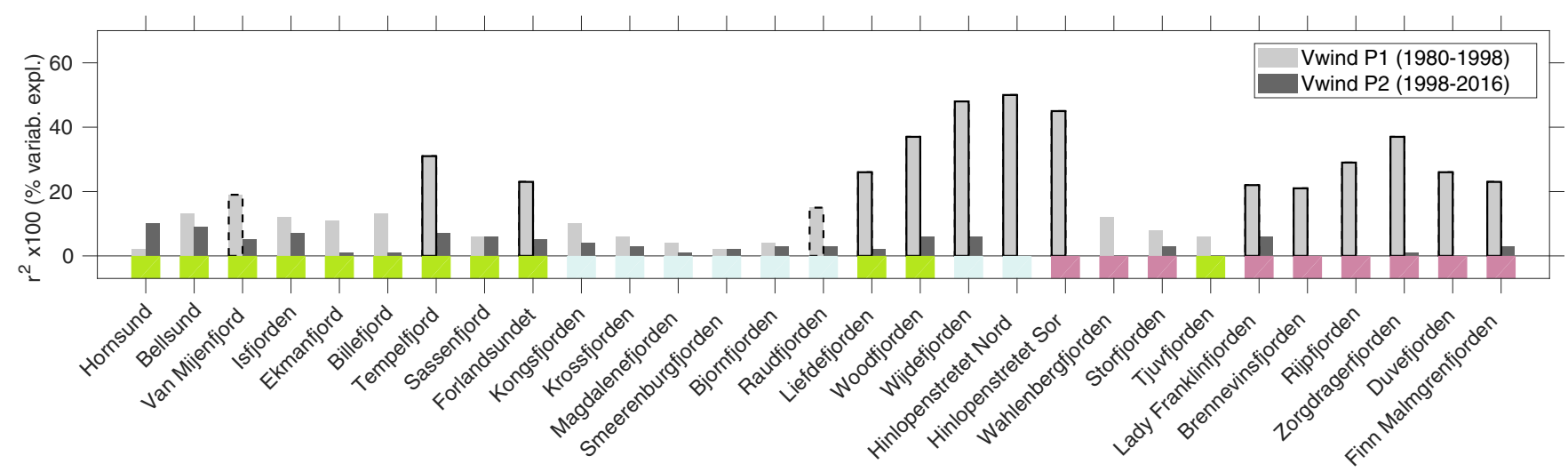

F I G U R E 10 Squared correlation coefficient between the meridional wind component at $1000 \mathrm{hPa}$, averaged over the Fram Box $\left(0-10^{\circ} \mathrm{E}, 78-81^{\circ} \mathrm{N}\right.$, see text for details) and regional SIE during DJF. For each SIE region, $r^{2}$ is computed for P1 (light grey bar) and P2 (dark grey bar) separately. Significance (90 and 95\%) of the correlations is indicated by dashed and solid outlines of the bars, respectively. The affiliation of each SIE region to one of the three patterns 1-3 discussed in this study is indicated by the coloured patches below each panel $(1=$ green, 2 = light blue, 3 = pink)

but applying the same analysis to any of the SAT time series from the 7 long term stations on Svalbard (see Table 1) yields qualitatively similar key results (not shown). This further builds on the robustness of the findings regarding the impact of large-scale SAT patterns on SIE across Svalbard.

It should be noted that the majority of correlations does not exceed the $r=-0.5-(-0.6)$ range, which translates to $r^{2}=25-36 \%$ explained variance. This points towards the potential role of other mechanisms that modulate the long-term SIE development additional to the strong correspondence with large-scale SAT patterns, however it must also be acknowledged in this context that the resolution and data quality of the sea ice charts increased over time and was more limited in the early years of the record (see Section 2.2).

\section{5 | DISCUSSION}

In Section 4.3 we investigate SIE/SAT covariability with lagged correlations and find that SAT can explain around $r^{2}=25-36 \%$ of SIE variability during winter. We emphasize, however, that the amount of sea ice cover in the Svalbard fjords is not simply a function of the local temperature but depends on a variety of physical processes. As atmospheric warming proceeds, increasing freshwater input by glacial meltwater may alter the fjord sea ice persistence and formation on the one hand, while on the other hand the freezing season shortens. Generally, the distribution of temperature and salinity within the WSC and the water column of the fjords itself plays an important role. For instance, Walczowski and Piechura (2011) have shown that warm oceanic water masses originating in the WSC can impact SAT on Svalbard during winter. Further, Kongsfjorden has the potential to become dominated by warm and salty Atlantic water masses via the penetration of WSC water into the fjord (Cottier et al., 2005), and Kongsfjorden SIC during winter is affected by heat transport in the upper water column (Sundfjord et al., 2017). Hence Cottier et al. (2007) proposed to add the oceanic part in the discussions on sea ice loss.

Another influencing factor for the fjord's sea ice distribution is given by the surface wind stress, both by advecting drift ice and mechanically destroying existing fast ice. As an example, Storfjorden SIE is primarily driven by the local atmospheric circulation (Skogseth et al., 2004). The timing of events with anomalous wind conditions or snowfall, and how they are coupled to the SAT and the oceanic state can be of crucial importance. For instance, a few days of very calm winds coinciding with low temperatures can lead to significant refreezing of large water areas, while snowfall after the freezing onset, or an enhanced fraction of warm and salty Atlantic water in the fjord would counteract the freezing, with strong implications during the melting/freezing season.

For the region east of Svalbard, King et al. (2017) have shown that sea ice advection from the Barents Sea can have substantial impact on the sea ice distribution and thickness. The distinct behaviour of pattern 2 SIE, namely the spatially confined increase during 1985-1995 is a striking feature that appears to go along with an increased sea ice export through Fram Strait during the same period (Vinje et al., 1998; Kwok and Rothrock, 1999; Hilmer and Jung, 2000; Smedsrud et al., 2017). Though the SIE-SAT correspondence across Svalbard is the main subject of our study, we have investigated relations during 
December-January-February (DJF) between SIE and the meridional wind component at $1000 \mathrm{hPa}$ from ERAInterim, area-averaged in the region $0-10^{\circ} \mathrm{E}, 78-81^{\circ} \mathrm{N}$. This area represents a box in the north-west of Svalbard, where pattern 2 SIE is observed. The resulting time series strongly resembles the Smedsrud et al. (2017) Fram Strait ice export estimates for DJF $(r=-0.87)$, that are based on the SLP difference across the entire Fram Strait. Figure 10 shows the squared correlation coefficients between the meridional wind and SIE. It can be seen that during P1 period, which contains the years of increase in SIE for pattern 2, the meridional wind in the northwest of Svalbard is significantly correlated with SIE in several regions mostly in the northern sector of the archipelago, where it explains more than $50 \%$ of SIE variability in some cases. It is conspicuous that the fjords and straits that are most influenced by the wind are those whose extent is pronounced in the north-south direction (Figure 2), with an opening to the north. This enables both effective sensible heat loss of the fjords open water surfaces by the northerly wind and advection of drift ice from the north. Significant correlations of wind with the group of pattern 3 regions (violet regions in Figure 10) should be handled with care, since winter SIE in these vicinities, at least during P1, has been close to $100 \%$, with little interannual variability. Furthermore, the above proposed link between meridional wind and SIC to explain the pattern 2 SIE increase in the 1980s and 1990s does not apply to all the pattern 2 fjords. Particularly a number of rather small fjords in the northwestern part of Svalbard show no significant connection with the meridional wind. However, it is striking that in $\mathrm{P} 2$, the wind-SIE correlation breaks down, demonstrated by the absence of significant correlations over all regions. A reasonable interpretation for this shift may be that fjords and straits whose SIE used to be coupled to the large scale atmospheric circulation and sea ice drift 3-4 decades ago have become increasingly independent from these processes over the last two decades. Instead, increased forcing of higher SAT may have become a more important factor, just like changes in the stratification, heat content, and salinity of the underlying ocean. Moreover, the increasing size and occurrence frequency of the wintertime polynya north of Svalbard (Onarheim et al., 2014) suppresses the availability of drift ice and modulates regional climate in its own.

\section{6 | CONCLUSIONS}

In this study, we have merged observational data on SIE and SAT from the Svalbard archipelago. The data reiterate the unprecedented, widely discussed winter-time warming and sea ice reduction for the region over the last 3-4 decades, including the SIE minimum in the recent years that are the lowest estimates since the beginning of our analysis time period in 1980. On the background of Arctic warming, Svalbard is in transition from winter-cold continental to a more maritime climate, with implications for the regional ecosystem both on land and in the fjord system. Climatologically, the west coast of the Svalbard archipelago is under maritime influence due to the presence of the WSC. Yet, we have shown that the annual temperature range is decreasing in recent years also in the central and eastern part of Svalbard, implying that the initially continental climate becomes more maritime in those climatological colder regions as well. The reduction in ATR is mostly due to increasing SAT during the winter months which also results in March having become the coldest month in the annual cycle throughout the archipelago. Also the SIE in the fjords along the coastline of Svalbard has changed over the last decades. Here, the development followed three different patterns that are spatialised to different Svalbard sub-regions. While on the west coast, the weak SIE reduction of the years since 1980 accelerated after the year 2000, the SIE in the north/northeast of Svalbard remained almost unaffected until the last 15-20 years when a strong decline has been observed. The fjords in the northern/northwestern part of Svalbard even experienced an increase in wintertime SIE in the period 1985 to 1995 before the recent strong decrease occurred. We have found that this earlier SIE increase may be partly caused by enhanced northerly winds during that period, and corresponding anomalous southward ice drift from the north during the 1980/90s, which was reported for Fram Strait by a number of studies (Vinje et al., 1998; Kwok and Rothrock, 1999; Smedsrud et al., 2017). While this effect of wind and ice drift on SIE was clearly visible in several fjords 3-4 decades ago, it has broken down in recent decades, when strong SAT forcing has overruled its effect. Though an additional impact on the local sea ice for instance by ocean currents, polynya formation, freshwater contribution, stratification or general sea surface temperature increase, is likely and not covered within our study, we can exclude the sea-ice insulation feedback as main local driver for the observed atmospheric warming, as the lag correlation between the monthly mean SIE and surface air temperature has clearly indicated that the atmospheric signal is leading the correlation. As ongoing climate change impacts both atmosphere and cryosphere in the Svalbard region, we conclude that on the analysed time scales SAT variability plays a substantial role in driving SIE anomalies in the Svalbard fjord systems, rather than vice versa.

We presume that an increased understanding of the recent connected changes of Svalbard climatology, 
meteorology and the cryosphere can prove very helpful as the baseline for near future changes in other regions of the Arctic as well. From our results, it can be inferred that with ongoing warming, it appears likely that the eastern Svalbard regions may become largely ice-free in winter as well, with large implications for the ecosystem and the local climate. Hence, studies on sea ice, meteorology and associated interaction processes, that are being conducted at the increasingly ice-free fjords in the west, can give valuable insights into the potential future fate of the northern and eastern regions of Svalbard. It can further be expected that the overarching warming and the increasing shift towards more subarctic conditions on Svalbard will accelerate and continue to impact marine biology and the abundance of Atlantic species, that have already been reported to increasingly spread northwestern Svalbard (Drinkwater, 2009; Buchholz et al., 2012; Berge et al., 2015).

\section{ACKNOWLEDGEMENTS}

We gratefully acknowledge the funding by the Deutsche Forschungsgemeinschaft (DFG, German Research Foundation)-Projektnummer 268020496-TRR 172, within the Transregional Collaborative Research Center "ArctiC Amplification: Climate Relevant Atmospheric and SurfaCe Processes, and Feedback Mechanisms (AC)3". Meteorological data are provided by the Norwegian Meteorological Institute (MET Norway), the Institute of Geophysics Polish Academy of Sciences (supported within statutory activities No 3841/E-41/S/2019 of the Ministry of Science and Higher Education of Poland) and the Arctic and Antarctic Research Institute (AARI). The collaboration was supported by the project "Quantifying Rapid Climate Change in the Arctic: regional feedbacks and large-scale impacts (QUARCCS)" funded by the German and Russian Ministries of Research and Education. The manuscript has benefitted from discussions with Robert Graham, Lana Cohen and Steve Hudson.

\section{ORCID}

Sandro Dahlke (iD https://orcid.org/0000-0002-0395-9597 Sebastian Gerland (10) https://orcid.org/0000-0002-2295-

9867

Tomasz Wawrzyniak (1D) https://orcid.org/0000-0003-3393$753 \mathrm{X}$

Marion Maturilli (i) https://orcid.org/0000-0001-68187383

\section{REFERENCES}

ACSYS (2003) ACSYS historical ice chart archive (1553-2002). IACPO Informal Report No. 8. Tromsø, Norway: Arctic Climate System Study.
Ambrose, W.G., Carroll, M.L., Greenacre, M., Thorrold, S.R. and McMahon, K.W. (2006) Variation in Serripes groenlandicus (bivalvia) growth in a Norwegian high-arctic fjord: evidence for local- and large-scale climatic forcing. Global Change Biology, 12(9), 1595-1607. https://doi.org/10.1111/j.1365-2486.2006. 01181.x.

Berge, J., Heggland, K., Lønne, O., Cottier, F., Hop, H., Gabrielsen, G., Nøttestad, G. and Misund, O. (2015) First records of Atlantic mackerel (Scomber scombrus) from the Svalbard archipelago, Norway, with possible explanations for the extension of its distribution. Arctic, 68(1), 54-61. https://doi. org/10.14430/arctic4455.

Box, J.E., Colgan, W.T., Christensen, T.R., Schmidt, N.M., Lund, M., Parmentier, F.-J., Brown, R., Bhatt, U.S., Euskirchen, E.S., Romanovsky, V.E., Walsh, J., Overland, J., Wang, M., Corell, R., Meier, W., Wouters, B., Mernild, S., Mård, J., Pawlak, J. and Olsen, M. (2019) Key indicators of arctic climate change: 1971-2017. Environmental Research Letters, 14(9), 045010.

Buchholz, F., Werner, T. and Buchholz, C. (2012) First observation of krill spawning in the high Arctic Kongsfjorden, west Spitsbergen. Polar Biology, 35(8), 1273-1279. https://doi.org/10. 1007/s00300-012-1186-3.

Burt, M.A., Randall, D.A. and Branson, M.D. (2016) Dark warming. Journal of Climate, 29(2), 705-719. https://doi.org/10.1175/ JCLI-D-15-0147.1.

Cohen, J., Screen, J.A., Furtado, J.C., Barlow, M., Whittleston, D., Coumou, D., Francis, J., Dethloff, K., Entekhabi, D., Overland, J. and Jones, J. (2014) Recent Arctic amplication and extreme mid-latitude weather. Nature Geoscience, 7(9), 627-637. https://doi.org/10.1038/ngeo2234.

Comiso, J.C. and Hall, D.K. (2014) Climate trends in the Arctic as observed from space. Wiley Interdisciplinary Reviews: Climate Change, 5(3), 389-409. https://doi.org/10.1002/wcc.277.

Cottier, F., Tverberg, V., Inall, M., Svendsen, H., Nilsen, F. and Griffiths, C. (2005) Water mass modification in an Arctic fjord through cross-shelf exchange: the seasonal hydrography of Kongsfjorden, Svalbard. Journal of Geophysical Research: Oceans, 110(C12), 1-18. https://doi.org/10.1029/2004JC002757.

Cottier, F., Nilsen, F., Inall, M., Gerland, S., Tverberg, V. and Svendsen, H. (2007) Wintertime warming of an Arctic shelf in response to large-scale atmospheric circulation. Geophysical Research Letters, 34(10), 1-5. https://doi.org/10.1029/2007GL029948.

Dahlke, S. and Maturilli, M. (2017) Contribution of atmospheric advection to the amplified winter warming in the Arctic North Atlantic Region. Advances in Meteorology, 2017, 1-8. https:// doi.org/10.1155/2017/4928620.

Dee, D.P., Uppala, S.M., Simmons, A., Berrisford, P., Poli, P., Kobayashi, S., Andrae, U., Balmaseda, M.A., Balsamo, G., Bauer, P., Bechtold, P., Beljaars, A., van de Berg, L., Bidlot, J.-R., Bormann, N., Delsol, C., Dragani, R., Fuentes, M., Geer, A.J., Haimberger, L., Healy, S.B., Hersbach, H., Hólm, E., Isaksen, L., Kallberg, P., Koehler, M., Matricardi, M., McNally, A.P., Monge-Sanz, B., Morcrette, J.J., Park, B., Peubey, C., de Rosnay, P., Tavolato, C., Thépaut, J.-N. and Vitart, F. (2011) The ERA-interim reanalysis: configuration and performance of the data assimilation system. Quarterly Journal of the Royal Meteorological Society, 137(656), 553-597. 
Divine, D.V. and Dick, C. (2006) Historical variability of sea ice edge position in the nordic seas. Journal of Geophysical Research: Oceans, 111(C1), 1-14. https://doi.org/10.1029/2004JC002851.

Drinkwater, K. (2009) Comparison of the response of Atlantic cod (Gadus morhua) in the high-latitude regions of the North Atlantic during the warm periods of the 1920s-1960s and the 1990s-2000s. Deep Sea Research Part II: Topical Studies in Oceanography, 56 (21), 2087-2096. https://doi.org/10.1016/j.dsr2.2008.12.001.

Esau, I. and Repina, I. (2012) Wind climate in Kongsfjorden, Svalbard, and attribution of leading wind driving mechanisms through turbulence-resolving simulations. Advances in Meteorology, 2012, 1-16. https://doi.org/10.1155/2012/568454.

Ewert, A. (1972) About calculating thermic continentality of climate. Przeglad Geograficzny, 44, 273-328 (in Polish).

Førland, E.J. and Hanssen-Bauer, I. (2003) Past and future climate variations in the Norwegian Arctic: overview and novel analyses. Polar Research, 22(2), 113-124.

Førland, E.J., Hanssen-Bauer, I. and Nordli, P. (1997) Climate statistics and longterm series of temperature and precipitation at Svalbard and Jan Mayen. Norwegian Meteorological Institute report Klima, nr. 21/97, 21, 72.

Gerland, S. and Hall, R. (2006) Variability of fast-ice thickness in Spitsbergen fjords. Annals of Glaciology, 44, 231-239. https:// doi.org/10.3189/172756406781811367.

Gerland, S. and Renner, A.H. (2007) Sea-ice mass-balance monitoring in an arctic fjord. Annals of Glaciology, 46, 435-442.

Gerland, S., Renner, A.H., Godtliebsen, F., Divine, D. and Lyning, T.B. (2008) Decrease of sea ice thickness at Hopen, Barents sea, during 1966-2007. Geophysical Research Letters, 35 (6), 1-5. https://doi.org/10.1029/2007GL032716.

Gjelten, H.M., Nordli, Ø., Isaksen, K., Førland, E.J., Sviashchennikov, P.N., Wyszynski, P., Prokhorova, U., Przybylak, R., Ivanov, B. and Urazgildeeva, A.V. (2016) Air temperature variations and gradients along the coast and fjords of western Spitsbergen. Polar Research, 35(1), 1-13. https://doi. org/10.3402/polar.v35.29878.

Graversen, R.G., Mauritsen, T., Tjernstrøm, M., Källén, E. and Svensson, G. (2008) Vertical structure of recent arctic warming. Nature, 451(7174), 53-56.

Hanssen-Bauer, I. and Førland, E. (1998) Long-term trends in precipitation and temperature in the Norwegian Arctic: can they be explained by changes in atmospheric circulation patterns? Climate Research, 10(2), 143-153.

Hanssen-Bauer, I., Solas, M.K. and Steffensen, E. (1990) Climate of Spitsbergen. DNMI rapport.

Hanssen-Bauer, I., Førland, E., Hisdal, H., Mayer, S., Sandø, A. and Sorteberg, A. (Eds.) (2019) Climate in Svalbard 2100-a knowledge base for climate adaption. NCCS report, nr. M-1242.

Hendricks, S., Gerland, S., Smedsrud, L., Haas, C., Pfaffhuber, A. and Nilsen, F. (2011) Sea-ice thickness variability in Storfjorden, Svalbard. Annals of Glaciology, 52(57), 61-68. https://doi.org/10.3189/172756411795931561.

Hilmer, M. and Jung, T. (2000) Evidence for a recent change in the link between the north atlantic oscillation and arctic sea ice export. Geophysical Research Letters, 27(7), 989-992. https://doi. org/10.1029/1999GL010944.

Høyland, K.V. (2009) Ice thickness, growth and salinity in van Mijenfjorden, Svalbard, Norway. Polar Research, 28(3), 339-352. https://doi.org/10.1111/j.1751-8369.2009.00133.x.
IPCC (2001) Climate Change 2001: The Scientific Basis. Contribution of Working Group I to the Third Assessment Report of the Intergovernmental Panel on Climate Change. Houghton, J.T., Ding, Y., Griggs, D.J., Noguer, M., van der Linden, P.J., Dai, X., Maskell, K. and Johnson C.A. (eds.) Cambridge University Press, Cambridge, United Kingdom and New York, NY, USA, 881pp.

Isaksen, K., Nordli, Ø., Førland, E.J., Łupikasza, E., Eastwood, S. and Niedźwiedź, T. (2016) Recent warming on Spitsbergen: influence of atmospheric circulation and sea ice cover. Journal of Geophysical Research: Atmospheres, 121(20), 11,913-11,931.

Isaksson, E., Kohler, J., Pohjola, V., Moore, J., Igarashi, M., Karlöf, L., Martma, T., Meijer, H., Motoyama, H., Vaikmäe, R. and van de Wal, R.S.W. (2005) Two ice-core $\delta 180$ records from Svalbard illustrating climate and sea-ice variability over the last 400 years. The Holocene, 15(4), 501-509.

Ivanov, B. (2019) Comparing the «earlier» and the «modern» warming in west Arctic on example of Svalbard. IOP conference series: Earth and environmental science. Turbulence, Atmosphere and Climate Dynamics, vol. 231

Jeffries, M.O., Overland, J.E. and Perovich, D.K. (2013) The Arctic shifts to a new normal. Physics Today, 66(10), 35-40. https:// doi.org/10.1063/PT.3.2147.

Kim, H.M. and Kim, B.-M. (2017) Relative contributions of atmospheric energy transport and sea ice loss to the recent warm Arctic winter. Journal of Climate, 30(18), 7441-7450. https:// doi.org/10.1175/JCLI-D-17-0157.1.

Kim, K.-Y., Hamlington, B.D., Na, H. and Kim, J. (2016) Mechanism of seasonal Arctic sea ice evolution and Arctic amplification. The Cryosphere, 10(5), 2191-2202.

Kim, K.-Y., Kim, J.-Y., Kim, J., Yeo, S., Na, H., Hamlington, B.D. and Leben, R.R. (2019) Vertical feedback mechanism of winter arctic amplification and sea ice loss. Scientific Reports, 9(1), 1184.

King, J., Spreen, G., Gerland, S., Haas, C., Hendricks, S., Kaleschke, L. and Wang, C. (2017) Sea-ice thickness from field measurements in the northwestern Barents sea. Journal of Geophysical Research: Oceans, 122(2), 1497-1512. https://doi.org/ 10.1002/2016JC012199.

Koch, L. (1945) The east Greenland ice, medd. Grønland, 130(3), 1-374.

Kortsch, S., Primicerio, R., Beuchel, F., Renaud, P.E., Rodrigues, J., Lønne, O.J. and Gulliksen, B. (2012) Climate-driven regime shifts in arctic marine benthos. Proceedings of the National Academy of Sciences, 109(35), 14052-14057. https://doi.org/10. 1073/pnas.1207509109.

Kwok, R. and Rothrock, D.A. (1999) Variability of Fram strait ice flux and North Atlantic Oscillation. Journal of Geophysical Research: Oceans, 104(C3), 5177-5189. https://doi.org/10.1029/ 1998JC900103.

Leu, E., Sreide, J., Hessen, D., Falk-Petersen, S. and Berge, J. (2011) Consequences of changing sea-ice cover for primary and secondary producers in the European arctic shelf seas: timing, quantity, and quality. Progress in Oceanography, 90(1), 18-32. https://doi.org/10.1016/j.pocean.2011.02.004.

Lind, S., Ingvaldsen, R.B. and Furevik, T. (2018) Arctic warming hotspot in the northern Barents Sea linked to declining sea-ice import. Nature Climate Change, 8, 634-639. https://doi.org/10. 1038/s41558-018-0205-y. 
Meier, W.N., Hovelsrud, G.K., van Oort, B.E., Key, J.R., Kovacs, K. M., Michel, C., Haas, C., Granskog, M.A., Gerland, S., Perovich, D.K., Makshtas, A. and Reist, J.D. (2014) Arctic sea ice in transformation: a review of recent observed changes and impacts on biology and human activity. Reviews of Geophysics, 52(3), 185-217. https://doi.org/10.1002/2013RG000431.

Muckenhuber, S., Nilsen, F., Korosov, A. and Sandven, S. (2016) Sea ice cover in Isfjorden and Hornsund, Svalbard (2000-2014) from remote sensing data. The Cryosphere, 10(1), 149-158. https://doi.org/10.5194/tc-10-149-2016.

Nilsen, F., Cottier, F., Skogseth, R. and Mattsson, S. (2008) Fjordshelf exchanges controlled by ice and brine production: the interannual variation of Atlantic water in Isfjorden, Svalbard. Continental Shelf Research, 28(14), 1838-1853. https://doi. org/10.1016/j.csr.2008.04.015.

Nordli, Ø., Przybylak, R., Ogilvie, A.E. and Isaksen, K. (2014) Longterm temperature trends and variability on Spitsbergen: the extended Svalbard Airport temperature series, 1898-2012. Polar Research, 33(1), 1-23. https://doi.org/10.3402/polar.v33.21349.

Onarheim, I.H., Smedsrud, L.H., Ingvaldsen, R.B. and Nilsen, F. (2014) Loss of sea ice during winter north of Svalbard. Tellus A: Dynamic Meteorology and Oceanography, 66(1), 1-9. https:// doi.org/10.3402/tellusa.v66.23933.

Onarheim, I.H., Eldevik, T., Årthun, M., Ingvaldsen, R.B. and Smedsrud, L.H. (2015) Skillful prediction of barents sea ice cover. Geophysical Research Letters, 42(13), 5364-5371. https:// doi.org/10.1002/2015GL064359.

Onarheim, I.H., Eldevik, T., Smedsrud, L.H. and Stroeve, J.C. (2018) Seasonal and regional manifestation of Arctic sea ice loss. Journal of Climate, 31, 4917-4932. https://doi.org/10.1175/ JCLI-D-17-0427.1.

Osuch, M. and Wawrzyniak, T. (2017) Inter-and intra-annual changes in air temperature and precipitation in western Spitsbergen. International Journal of Climatology, 37(7), 3082-3097.

Pavlov, A.K., Tverberg, V., Ivanov, B.V., Nilsen, F., FalkPetersen, S. and Granskog, M.A. (2013) Warming of Atlantic Water in two west Spitsbergen fjords over the last century (1912-2009). Polar Research, 32(1), 1-14. https://doi.org/10. 3402/polar.v32i0.11206.

Pavlova, O., Gerland, S. and Hop, H. (2019) Changes in sea-ice extent and thickness in Kongsfjorden, Svalbard (2003-2016). In: Hop, H. and Wiencke, C. (Eds.) The ecosystem of Kongsfjorden, Svalbard. Cham, Switzerland: Springer International Publishing, pp. 105-136.

Przybylak, R., Araźny, A., Nordli, Ø., Finkelnburg, R., Kejna, M., Budzik, T., Migała, K., Sikora, S., Puczko, D., Rymer, K. and Rachlewicz, G. (2014) Spatial distribution of air temperature on Svalbard during 1 year with campaign measurements. International Journal of Climatology, 34, 3702-3719. https://doi.org/10. 1002/joc.3937.

Rösel, A., Itkin, P., King, J., Divine, D., Wang, C., Granskog, M.A., Krumpen, T. and Gerland, S. (2018) Thin sea ice, thick snow and widespread negative freeboard observed during N-ICE2015 north of Svalbard. Journal of Geophysical Research: Oceans, 123, 1156-1176. https://doi.org/10.1002/2017JC012865.

Scheuchl, B., Flett, D., Caves, R. and Cumming, I. (2004) Potential of Radarsat-2 data for operational sea ice monitoring. Canadian Journal of Remote Sensing, 30(3), 448-461. https://doi.org/10. 5589/m04-011.
Screen, J.A. and Simmonds, I. (2010) The central role of diminishing sea ice in recent Arctic temperature amplification. Nature, 464(7293), 1334-1337.

Sen, P.K. (1968) Estimates of the regression coefficient based on Kendall's tau. Journal of the American Statistical Association, 63 (324), 1379-1389.

Serreze, M.C. and Barry, R.G. (2011) Processes and impacts of Arctic amplification: a research synthesis. Global and Planetary Change, 77(1), 85-96. https://doi.org/10.1016/j.gloplacha.2011.03.004.

Serreze, M.C., Barrett, A., Stroeve, J.N., Kindig, D. and Holland, M. (2009) The emergence of surface-based Arctic amplification. The Cryosphere, 3, 11-19.

Skogseth, R., Haugan, P.M. and Haarpaintner, J. (2004) Ice and brine production in Storfjorden from four winters of satellite and in situ observations and modeling. Journal of Geophysical Research: Oceans, 109(C10), 1-15. https://doi.org/10.1029/ 2004JC002384.

Smedsrud, L.H., Halvorsen, M.H., Stroeve, J.C., Zhang, R. and Kloster, K. (2017) Fram Strait sea ice export variability and September Arctic sea ice extent over the last 80 years. The Cryosphere, 11(1), 65-79. https://doi.org/10.5194/tc-11-65-2017.

Steig, E.J., Schneider, D.P., Rutherford, S.D., Mann, M.E., Comiso, J.C. and Shindell, D.T. (2009a) Warming of the Antarctic ice-sheet surface since the 1957 International Geophysical Year. Nature-Corrigendum, 460, 766. https://doi.org/10.1038/ nature 08286 .

Stroeve, J., Holland, M., Meier, W., Scambos, T. and Serreze, M. (2007) Arctic sea ice decline: faster than forecast. Geophysical Research Letters, 34(9), 1-5. https://doi.org/10.1029/2007GL029703.

Stroeve, J., Serreze, M., Holland, M., Kay, J., Malanik, J. and Barrett, A. (2012) The Arctics rapidly shrinking sea ice cover: a research synthesis. Climatic Change, 110(3-4), 1005-1027.

Sundfjord, A., Albretsen, J., Kasajima, Y., Skogseth, R., Kohler, J., Nuth, C., Skarðhamar, J., Cottier, F., Nilsen, F., Asplin, L., Gerland, S. and Torsvik, T. (2017) Effects of glacier runoff and wind on surface layer dynamics and Atlantic water exchange in Kongsfjorden, Svalbard; a model study. Estuarine, Coastal and Shelf Science, 187, 260-272.

Theil, H. (1950) A rank-invariant method of linear and polynominal regression analysis (parts 1-3). Nederlandse Akademie van Wetenschappen Proceedings Series A, 53, 1397-1412.

Tislenko, D.I., Ivanov, B.V., Smolyanitky, V.M., Svyashchennikov, P. N., Isaksen, K. and Gjelten, H. (2016) Seasonal and longterm changes of sea ice extent in the Svalbard archipelago area during 1979-2015. AARI Proceedings, 109(3), 50-59.

Torres, R., Snoeij, P., Geudtner, D., Bibby, D., Davidson, M., Attema, E., Potin, P., Rommen, B., Floury, N., Brown, M., Traver, I.N., Deghaye, P., Duesmann, B., Rosich, B., Miranda, N., Bruno, C., L'Abbate, M., Croci, R., Pietropaolo, A., Huchler, M. and Rostan, F. (2012) Gmes sentinel-1 mission. Remote Sensing of Environment, 120, 9-24. https://doi.org/10.1016/j.rse.2011.05.028.

Vinje, T. (2001) Anomalies and trends of sea-ice extent and atmospheric circulation in the nordic seas during the period 1864-1998. Journal of Climate, 14(3), 255-267. https://doi.org/ 10.1175/1520-0442(2001)014<0255:AATOSI >2.0.CO;2.

Vinje, T., Nordlund, N. and Kvambekk, A. (1998) Monitoring ice thickness in Fram strait. Journal of Geophysical Research: Oceans, 103(C5), 10437-10449. https://doi.org/10.1029/ 97JC03360. 
Walczowski, W. and Piechura, J. (2011) Influence of the West Spitsbergen Current on the local climate. International Journal of Climatology, 31(7), 1088-1093.

Wang, C., Cheng, B., Wang, K., Gerland, S. and Pavlova, O. (2015) Modelling snow ice and superimposed ice on landfast sea ice in Kongsfjorden, Svalbard. Polar Research, 34(1), 1-16. https://doi. org/10.3402/polar.v34.20828.

Wendisch, M., Brückner, M., Burrows, J., Crewell, S., Dethloff, K., Ebell, K., Lüpkes, C., Macke, A., Notholt, J., Quaas, J., Rinke, A. and Tegen, I. (2017) Understanding causes and effects of rapid warming in the Arctic. Eos, 98. https://doi.org/ 10.1029/2017EO064803.

Yue, S., Pilon, P., Phinney, B. and Cavadias, G. (2002) The influence of autocorrelation on the ability to detect trend in hydrological series. Hydrological Processes, 16(9), 1807-1829.
Zhuravskiy, D., Ivanov, B. and Pavlov, A. (2012) Ice conditions at Gronfjorden bay, Svalbard, from 1974 to 2008. Polar Geography, 35(2), 169-176. https://doi.org/10.1080/1088937X.2012. 662535 .

How to cite this article: Dahlke S, Hughes NE, Wagner PM, et al. The observed recent surface air temperature development across Svalbard and concurring footprints in local sea ice cover. Int J Climatol. 2020;40:5246-5265. https://doi.org/10. 1002/joc.6517 